\title{
What we know about management accountants' changing identities and roles - a systematic literature review
}

Management accountants' changing identities and roles

\author{
Tanja Wolf \\ Institute of Management Control and Consulting, \\ Johannes Kepler University Linz, Linz, Austria \\ Michael Kuttner
}

Institute of Management Control and Consulting, Johannes Kepler University Linz, Linz, Austria and Department of Management Accounting and Finance, Business School, Salzburg University of Applied Sciences, Salzburg, Austria

\author{
Birgit Feldbauer-Durstmüller \\ Institute of Controlling and Consulting, \\ Johannes Kepler University Linz, Linz, Austria, and \\ Christine Mitter \\ Department of Management Accounting and Finance, Business School, \\ Salzburg University of Applied Sciences, Salzburg, Austria
}

\begin{abstract}
Purpose - Academic interest in role changes of management accountants (MAs) has increased during the past two decades. Role changes imply identity reconstructions as they do not only require an external legitimacy, but professionals have to internalize a new role script. Thus, this paper aims to contribute to a comprehensive understanding of the ongoing changes concerning MAs by providing an identity perspective.

Design/methodology/approach - This paper systematically reviews the literature on the changing role of MAs from an identity perspective, based on a conclusive sample of 64 articles.

Findings - This review identified several external factors such as professional associations and educational institutions as well as organizational and individual factors that impact MAs' identity and act as change drivers. MAs' identity is linked with their image in the public and within the organization and is challenged by increasing demands, conflicting expectations and technological progress. Hence, the literature sample illustrates a fragmented and contradictory picture regarding the changes of MAs' identities and roles and

(C) Tanja Wolf, Michael Kuttner, Birgit Feldbauer-Durstmüller and Christine Mitter. Published by Emerald Publishing Limited. This article is published under the Creative Commons Attribution (CC BY 4.0) licence. Anyone may reproduce, distribute, translate and create derivative works of this article (for both commercial and non-commercial purposes), subject to full attribution to the original publication and authors. The full terms of this licence may be seen at http://creativecommons.org/ licences/by/4.0/legalcode

The authors would like to thank Johannes Thaller for his assistance during the literature search and Nadine Bachmann for proofreading our manuscript. Moreover, the authors appreciate the encouraging comments, helpful notes and suggestions from the reviewers and the participants of the Annual Congress of the European Accounting Association (EAA) in Cyprus 2019.
\end{abstract}

Received 15 March 2019 Revised 26 November 2019 27 April 2020

Accepted 25 May 2020

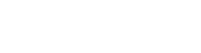


JAOC 16,3

displays that the idea of a simple movement from one identity to another is misleading. Furthermore, the identity perspective offers new issues for management accounting research, practice and education such as nested identity, multiple or desired identities.

Originality/value - To the best of the authors' knowledge, this study is the first to review the literature of MAs' changing identities and roles from an identity perspective. This perspective enables a novel focus on internal views, perceptions and internalized meanings of MAs connected with their role instead of exclusively debating changed external behavior expectations.

Keywords Change, Identity, Management accounting, Role, Management accountant

Paper type Literature review

\section{Introduction}

Various developments, such as advancing globalization, increasing worldwide business networking, novelties in information technology (IT), the growing influence of professional organizations, the academization of the profession and, above all, the intensive use of management accounting in business practice are responsible for continuous changes of management accounting. However, these developments affect not only management accounting but also its task carrier, the management accountant (MA). Nowadays, there is a lively scientific discourse about the MA; for instance, an extensive number of publications deal with the changing role of MAs from the so-called bean counter to the business partner (Baldvinsdottir et al., 2009; Byrne and Pierce, 2007; Järvenpää, 2007). When role changes are propagated, there is not only an external legitimacy needed, but the professionals have to internalize a new role script (Goretzki et al., 2013; Järvenpää, 2001; Windeck et al., 2015; Yazdifar and Tsamenyi, 2005), which refers to the identity concept. Identities and roles can be considered as two sides of the same coin: identity looks inward to one's self-definition and encompasses the internalized meanings and internal expectations connected with a role, whereas role looks outward to the interaction arrangement in an organizational setting and focuses on external behavior expectations related to a social position (Barley, 1989; Chreim et al., 2007; Goretzki et al., 2013; Stryker and Burke, 2000).

Just a few articles directly mention the identity concept, thereby covering heterogeneous topics. Ahrens and Chapman (2000) compare the identities of MAs in Britain and Germany, whereas Järvinen (2009) focuses on identities of MAs in the public sector in Finland. Case studies explicate the link between role changes and reconstruction of identities as described by Goretzki et al. (2013) or discuss the tensions between existing and idealized identities as presented by Morales and Lambert (2013). Taylor and Scapens (2016) as well as Hiller et al. (2014) link identity with the image of MAs. Heinzelmann (2018) investigates the impact of IT systems on the identities of MAs, whereas Horton and de Araujo Wanderley (2018) examine multiple identities and identity conflicts. Goretzki and Messner (2019) explain the identity project of MAs as business partners in a broader interaction context, whereas Morales (2019) describes the shaping of a common identity of MAs by symbolic categorizations. Further articles explain that changes in the roles came along with changes in the perceptions of MAs themselves. Therefore, they indirectly consider identity, although they do not directly mention this concept (Burns and Baldvinsdottir, 2005; Endenich et al., 2017; Hopper, 1980).

Particularly in change situations, identities of MAs are to be continuously reformed (Ahrens and Chapman, 2000; Alvesson and Willmott, 2002; Giddens, 1991; Järvinen, 2009). Therefore, this paper aims to contribute to a comprehensive understanding of the ongoing changes concerning MAs by focusing on their identities, to deliver a structured overview of the current state of research, to identify research gaps, to provide new perspectives on identity and role changes of MAs, to show possible implications for research, practice as well as education and thus to motivate scholars to contribute to this field of research. For this reason, the paper analyzes and synthesizes the extant literature on MAs by conducting 
a systematic literature review following the methodology proposed by Tranfield et al. (2003) and Massaro et al. (2016). The search was guided by the research question "What is known about changing identities and roles of management accountants?" Scrutinizing the papers from an identity perspective implies that we concentrate on internal, cognitive processes of MAs, their characteristics, experiences, motivations, goals, values, beliefs, norms and interaction styles (Ashforth, 2001; Oyserman et al., 2012). Focus areas of the literature are aggregated into a conceptual framework, which provides a comprehensive overview of the existing knowledge in the literature as well as a foundation for synthesis and further discussion. Acknowledging that identity is only partially formed in workplaces (Ashforth et al., 2008; Brewer and Gardner, 1996; Järvinen, 2009; Postmes and Jetten, 2006), this systematic literature review focuses on professional identities.

Our paper is structured as follows. In Section 2, we discuss management accounting and MAs, the theoretical bases of identity, the main differences and relations between identity and role as well as our conceptual framework. Section 3 explains the methodology, followed by characteristics of the reviewed articles in Section 4. Section 5 provides a profound discussion of the findings of our literature review. The conclusion summarizes the findings and presents implications for research, practice and education as well as the limitations of the paper.

\section{Theoretical background}

\subsection{Management accounting and management accountants}

A broad and commonly used definition of management accounting is stated by the Institute of Management Accountants (IMA) (2008, p. 1), arguing that management accounting:

[...] involves partnering in management decision making, devising planning and performance management systems, and providing expertise in financial reporting and control to assist management in the formulation and implementation of an organization's strategy.

An MA is understood as the task carrier of management accounting practices and, especially in the past two decades, it is propagated that MAs have developed from traditional bean counters to business partners (Granlund and Lukka, 1997; Järvenpää, 2007; Sorensen, 2009).

Our literature sample presents country-specific differences in the historical and theoretical development of management accounting concepts, which is displayed in diverse terms, approaches and institutional contexts. In some European countries, the MA is labeled as "controller" and the interchangeable use of these two terms is commonly found in the analyzed literature (Ahrens and Chapman, 2000; de Loo et al, 2011; Oesterreich and Teuteberg, 2019; Verstegen et al., 2007). A further noteworthy difference is the separation of financial and management accounting in several European countries, which results in processes organized into two separate cycles. Anglo-Saxon countries refer to a more integrated approach, and thus in the English-speaking literature, the explicit differentiation between financial accountants and MAs is often lacking. In studies from Germany, France or Italy, management accounting focuses more on supporting decision-making, whereas financial accounting is primarily responsible for meeting the statutory requirements (Albu et al., 2011; Caglio, 2003). Regarding the institutional context, there are strong professional bodies in the UK and the USA, whereas in countries such as Germany or France, there is a low degree of professionalization. In these countries, an MA does not require a certificate by a professional association and thus the recognition as a profession is relatively low (Ahrens and Chapman, 2000; Goretzki et al., 2013; Goretzki and Messner, 2019; Lambert and Pezet, 2011).

\subsection{Identity and role}

As role theory is elaborated in many management accounting papers (Byrne and Pierce, 2007; Byrne and Pierce, 2018; Goretzki et al., 2013), we concentrate on identity theory but
Management accountants'

changing identities and roles

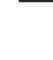


JAOC 16,3

aim to explain the differences and relations between identity and role. Different disciplines, such as psychology, anthropology, sociology and other social sciences, are discussing these two concepts. Additionally, within each of these disciplines, different research streams have developed and there is a wide range of how identity can be conceptualized (Biddle, 2013; Kreiner et al., 2006; Stryker and Burke, 2000; Schwartz et al., 2011; Vignoles et al., 2011).

There are different bases of identity deriving from the membership of a social group (Hogg and Abrams, 1988; Stryker and Burke, 2000; Tajfel, 1978; Tajfel and Turner, 1979) or the occupation of a role (Burke and Tully, 1977; Stets and Burke, 2000; Stryker and Burke, 2000; Thoits, 1983, 1986). Furthermore, the concept can be defined at an individual, collective or relational level. As identity basically encompasses one's response to the question "Who are you?" this "you" can be singular or plural and therefore identity can refer to the self-definitions of individuals or groups (Ashforth et al., 2008; Vignoles et al., 2011). All these different approaches are not necessarily incompatible. A complete theory considers the group and the role bases of identity as well as the bases in the person itself (Stets and Burke, 2000). Consequently, Burke and Stets (2009) define identity as a set of meanings describing an individual as an occupant of a role or as a member of a group, or claiming particular characteristics to identify one as a unique person. Furthermore, identities are social products as individuals exist within the context of social structures and they are shaped through interactions with others (Burke and Reitzes, 1981; Burke and Stets, 2009). Identity is formed during an individual's lifespan through the interplay of processes of self-discovery and personal interpretations as well as of social interactions. As the concept can be explained at an individual, collective or relational level, identity consists of self-chosen personal characteristics and beliefs about oneself, one's membership in groups as well as roles in relation to significant others (Vignoles et al., 2011).

The term "role" is discussed in modern science since the work of Linton (1936), who defines role as a set of behaviors linked to the inhabited status. According to Biddle (1986, 2013), role theorists primarily refer to external norms, outward behavior expectations and descriptions for explaining the term "role." Thus, roles are induced by shared expectations of other organization members. Management accounting literature discusses these outside expectations (Byrne and Pierce, 2018); however, the term "role" mainly relates to different functions and tasks of MAs (Rieg, 2018; Jack and Kholeif, 2008; Oesterreich and Teuteberg, 2019). Figure 1 displays the main differences between identity and role: identity is internal and focuses on inner dynamics, internalized meanings and internal expectations, whereas a role is external and linked to positions within social structures (Stryker and Burke, 2000).

Despite the differences between these two concepts, identity is closely interconnected with the enactment of roles. Identity includes how the role occupant interprets and makes sense of a role. The external description of a role is likely to affect the way people think about the role, whereas a person's identity influences the way one enacts this role. Consequently, role and identity evolve interactively and thus the terms are often used interchangeably in the literature (Ashforth, 2001; Barley, 1989; Chreim et al., 2007; Pratt et al., 2006).

From a management perspective, identity is essential as it influences people's attitudes and behaviors (Ashforth and Mael, 1989; Haslam and Ellemers, 2011). Professional identity is regarded as a major element of identity and means one's perception of work-related interests, abilities, goals and values (Kielhofner, 2002; Schwartz et al., 2011; Skorikov and Vondracek, 2011). This systematic literature review focuses on professional identities of MAs, including their characteristics, experiences, motivations, goals, values, beliefs, internal norms and interaction styles (Ashforth, 2001; Ashforth et al., 2008; Chreim et al., 2007). 


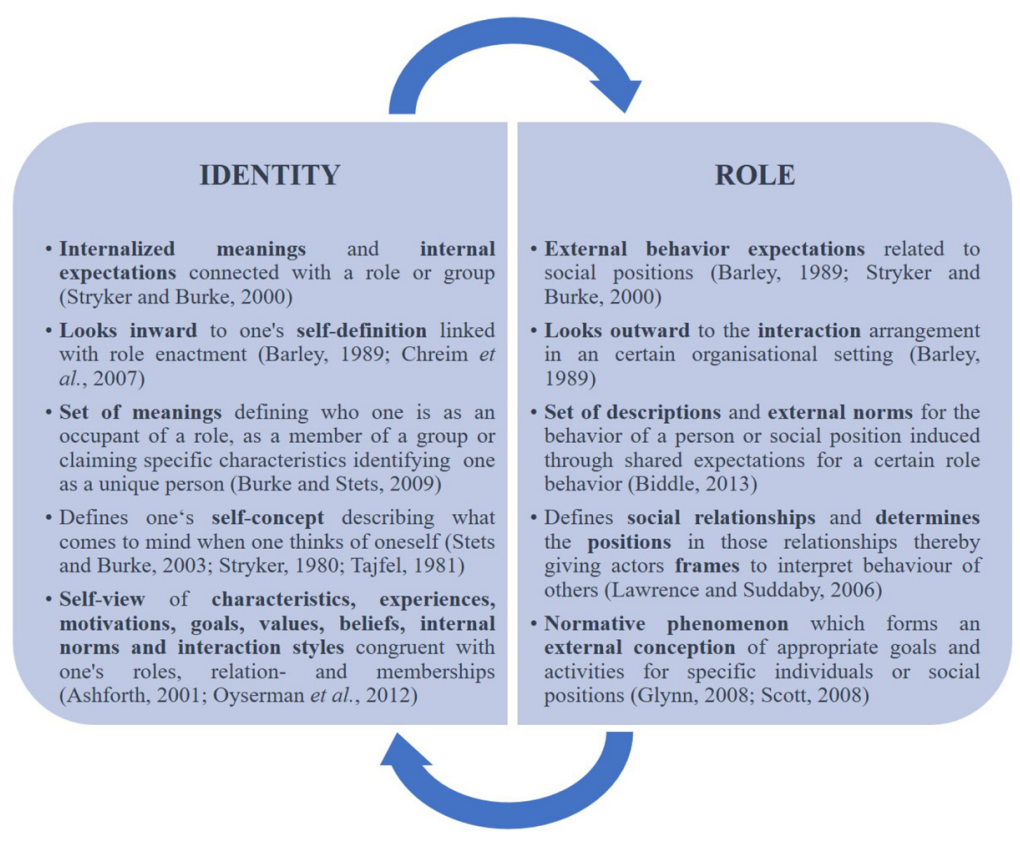

\section{Management accountants' changing identities and roles}

315

Figure 1.

Differences between identity and role

\subsection{Conceptual framework of identity changes}

Our conceptual framework systematizes the focus areas of the literature for delivering a comprehensive overview of the existing knowledge and a foundation for synthesis and further discussion. The framework integrates previous studies about the identity of MAs, thereby considering diverse research streams of identity theory. Thus, we concurrently take into account the linkages of social structures with identities as well as the internal dynamics of individuals (Stryker and Burke, 2000). External and organizational aspects represent the influence of social structures and are closely linked. Furthermore, several organizational aspects are intertwined with individual ones and classifying some factors as either organizational or individual involves a certain level of arbitrariness (Chreim et al., 2007).

External aspects include professional associations and educational institutions, legislation and compliance as well as the public image of MAs. Professional associations and educational institutions can confine or support the understanding of identities. While legislation specifies what a professional should accomplish, professional associations reinforce changes by providing fundamental or alternative templates determining what constitutes professionalism (Chreim et al., 2007; Cooper and Robson, 2006). Despite the popular template of the business partner, there is still a discussion about the influence of increased legislation and compliance regulation on MAs (Byrne and Pierce, 2007; de Loo et al., 2011). Social identity theory indicates clear connections between the identity and image of group members (Dutton and Dukerich, 1991; Gioia and Thomas, 1996; Taylor and Scapens, 2016).

Organizational arrangements, for instance, the decision whether management accounting is centralized or decentralized, enable new constellations of interactions, and identity changes require an organizational embeddedness (Chreim et al., 2007; Goretzki et al., 2013; Wolf et al., 2015). Järvenpää (2007) describes necessary organizational processes for 
JAOC 16,3

316

the business orientation of MAs, among others image construction, introduction of new information systems and decentralization. MAs' perceived image within organizations influences their self-concepts and identification with the profession and organization (Hiller et al., 2014; Taylor and Scapens, 2016). Implications of information systems and digitalization as decisive issues are intensively debated in the literature sample (Järvenpää, 2007; Oesterreich and Teuteberg, 2019). Furthermore, the literature sample focuses on decentralization as crucial for the proximity of managers and MAs. This might result in a nested identity, meaning that MAs identify more with their colleagues onsite than with their profession in the organization (Granlund and Lukka, 1998; Horton and de Araujo Wanderley, 2018; Vaivio, 2004). Considering identity as a relational phenomenon - because individuals come to know who they are through their interactions with others - leads to patterns of interaction (Ahrens and Chapman, 2000; Burke and Stets, 2009). Management accounting is considered as inherently contextual, and thus contingency factors might have an effect on the identity of MAs (Morales, 2019; Goretzki and Messner, 2019). Consequently, organizational aspects comprise image within the organization, contingency factors, information systems and digitalization, patterns of interaction as well as decentralization and nested identity.

Especially in change situations, the continuous rethinking of identities by MAs is necessary, and such processes depend on their competencies and characteristics (Ahrens and Chapman, 2000; Alvesson and Willmott, 2002; Giddens, 1991; Järvinen, 2009). Bearing in mind that individuals occupy as many identities as relationships in which they fulfil roles, multiple identities and identity conflicts might evolve (Brewer, 1999; Burke and Stets, 2009; Horton and de Araujo Wanderley, 2018). Regarding possible identity conflicts, individuals do not passively follow social pressures, but rather actively position themselves within conflicting identity options. Consequently, professionals might support those changes which are consistent with their desired identity (Horton and de Araujo Wanderley, 2018; Morales and Lambert, 2013; Oyserman and James, 2011). Thus, individual aspects encompass multiple identities, identity conflicts, competencies and characteristics, as well as desired and ideal identity. Figure 2 illustrates our conceptual framework.

\section{Methodology}

For conducting this systematic literature review, we followed the methodology suggested by Tranfield et al. (2003) and Massaro et al. (2016), alongside other reviews within the research field of management accounting (Ndemewah et al., 2019; Nguyen et al., 2018; Senftlechner and Hiebl, 2015). Following Massaro et al. (2016, p. 767), systematic literature reviews are a

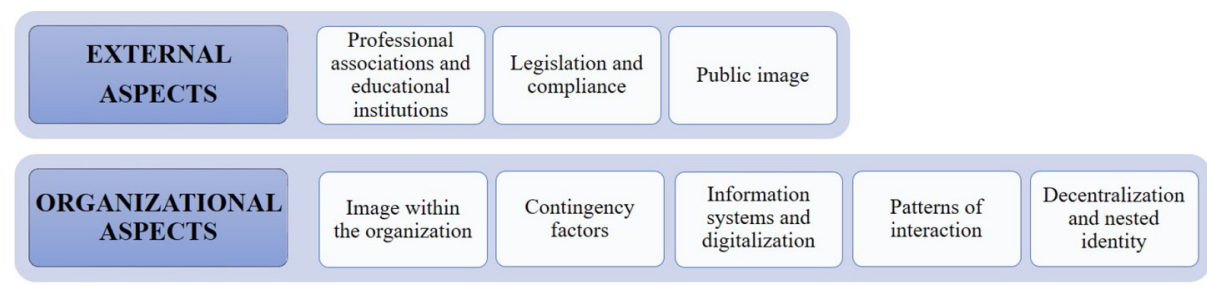

Figure 2.

Framework of identity changes

\begin{tabular}{|c|c|c|c|c|c|c|c|}
\hline $\begin{array}{c}\text { Identity } \\
\text { conflicts } \\
\text { identities }\end{array}$ & $\begin{array}{c}\text { Competencies } \\
\text { and } \\
\text { characteristics }\end{array}$ \\
$\begin{array}{c}\text { Desired and } \\
\text { ideal identity }\end{array}$ \\
\hline
\end{tabular}


suitable "method for studying a corpus of scholarly literature, to develop insights, critical reflections, future research paths and research questions."

To identify relevant literature, we conducted a keyword search within seven databases (EBSCO, ProQuest, ScienceDirect, Scopus, Springer Link, Web of Science and Wiley Online Library). Our literature search was limited to journal articles in English-language on MAs' identity or role. However, in line with Kubíček and Machek (2018, p. 967), we "did not limit the results to any particular preselected class of journals" to include findings from journals, which are not listed within a journal ranking (Academic Journal Guide (AJG), 2018). To be considered within the sample, only a review-process within the journal was required. Furthermore, we placed no restrictions concerning the time of publications. Consequently, all matching articles were considered until the end of our literature search in August 2019. We searched within title, abstract and keywords for two different groups of keywords combined with an "AND" conjunction. The first group of keywords refers to management accounting and synonyms (according to Chenhall (2003), terms such as management accounting, management control and managerial accounting are often used interchangeably) and the second keyword group contained identity and role: [("management account*” OR "managerial account*" OR "management control*” OR "cost account*”) AND ("identity" OR "role")]. Moreover, a spreadsheet was prepared to document the search and data extraction process, to ensure the academic quality and reproducibility of this systematic literature search.

The initial search process resulted in 2,829 hits. In the next step, we excluded all duplicates (816) and publications $(1,882)$ containing no information about MAs' changing identities and roles within the abstract. For the remaining 131 publications, full texts were analyzed, whereby 48 publications remained for our systematic literature review. Furthermore, we scanned the references of the 48 publications to identify additional studies and used Google Scholar [1] to search for additional articles by the identified authors. We identified 16 additional articles, resulting in a final sample of 64 peer-reviewed journal articles (Figure 3 summarizes the search process).

After determining the final sample, we started to analyze the publications as suggested by Massaro et al. (2016) and Tranfield et al. (2003). Similar to prior reviews in the field of business and management (Senftlechner and Hiebl, 2015), studies that contain "more" information regarding our research focus were regarded as "richer" and are more often cited.

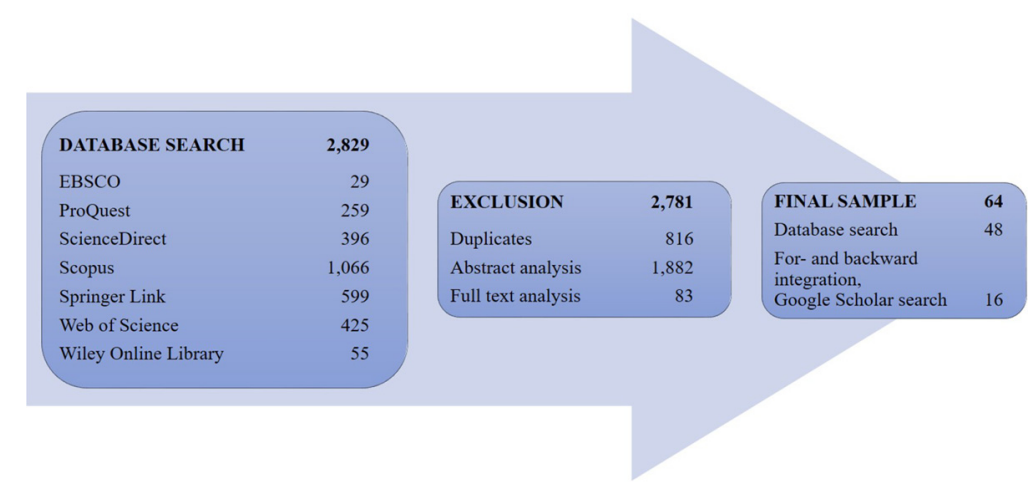

Figure 3. Selection process 
JAOC

16,3

318

\section{Characteristics of the reviewed articles}

4.1 Journals, rankings and timeline of the reviewed articles

Table 1 summarizes all journals, rankings and the timeline of publications. Sample publications are spread over 30 different journals. Along their self-declared aims and interests, the vast majority of the journals (19) are accounting journals. In total, 50 articles were published in peer-reviewed accounting journals, and only 14 within journals of other research fields (e.g. business and management journals), which may indicate a lack of interdisciplinary studies within the research field and/or a lack of general interest in this topic.

The majority (24) of the journals are ranked within the AJG 2018 [2] and/or VHB JQ3 [3] and/or possess a JIF 2018 [4]. The number of sample articles within the journals counts between one and four, except the European Accounting Review (10), Management Accounting Research (7) and Accounting, Organizations and Society (7). Furthermore, the vast majority of our sample publications were published since 2000 (51). The oldest publication is by Hopper (1980) and is one of six publications published before 1996. From 2016 onwards, 15 publications about MAs' identities or roles were published, which could indicate an increasing interest within academia.

\subsection{Descriptive information of the reviewed articles}

Descriptive information of the 64 sample publications (e.g. article type, data collection, time frame, sample information) is summarized in Table 2. In total, our sample involves 7 conceptual theoretical publications, 15 empirical-quantitative and 38 empirical-qualitative studies. In the remaining four studies, a mixed-method research approach was applied.

Authors mainly collected data through interviews (38), surveys (17) or analyzed secondary data (24), for instance, job advertisements (Azan and Bollecker, 2011). Secondary data were often used to complement and enrich findings. Lambert and Sponem (2012), for instance, used archival materials in addition to interviews within their study. Regarding the time span of investigation, most of our empirical sample articles contain cross-sectional studies (46), and only in 12 cases, a longitudinal investigation was carried out. Only Erhart et al. (2017) conducted a cross-sectional and a longitudinal study.

Publications also show a great heterogeneity because of sample size as well as sample choice. Authors investigated MAs in one company or more, with the greatest quantity being up to several hundred companies of different size and industry, with strong focus on large companies. Furthermore, in most cases, research was conducted within Europe; studies from North America or Asia are sparse within our sample publications.

We also analyzed the sample publications in relation to how far a theoretical background or theory explained the findings. Within the vast majority of the studies, no theory (34) was explicitly mentioned, which could be an indicator for the missing theoretical substantiation of the research field. However, most of the younger publications in high-ranked journals refer to a theory (Baldvinsdottir et al., 2009; Taylor and Scapens, 2016). Applied theories show a broad range, for instance, institutional theory (Granlund and Lukka, 1997; Burns and Baldvinsdottir, 2005), social identity theory (Horton and de Araujo Wanderley, 2018) and role theory (Byrne and Pierce, 2007).

\subsection{Temporal development of management accountants' identities and roles}

The first articles about roles from the 1980s start with role conflicts (Hopper, 1980; Sathe, 1983). Remarkably, role and identity conflicts are still discussed nearly 40 years later (Amilin, 2017; Byrne and Pierce, 2018; Horton and de Araujo Wanderley, 2018). Already in the 1980s, the active role of MAs in the development and implementation of IT is a topic 


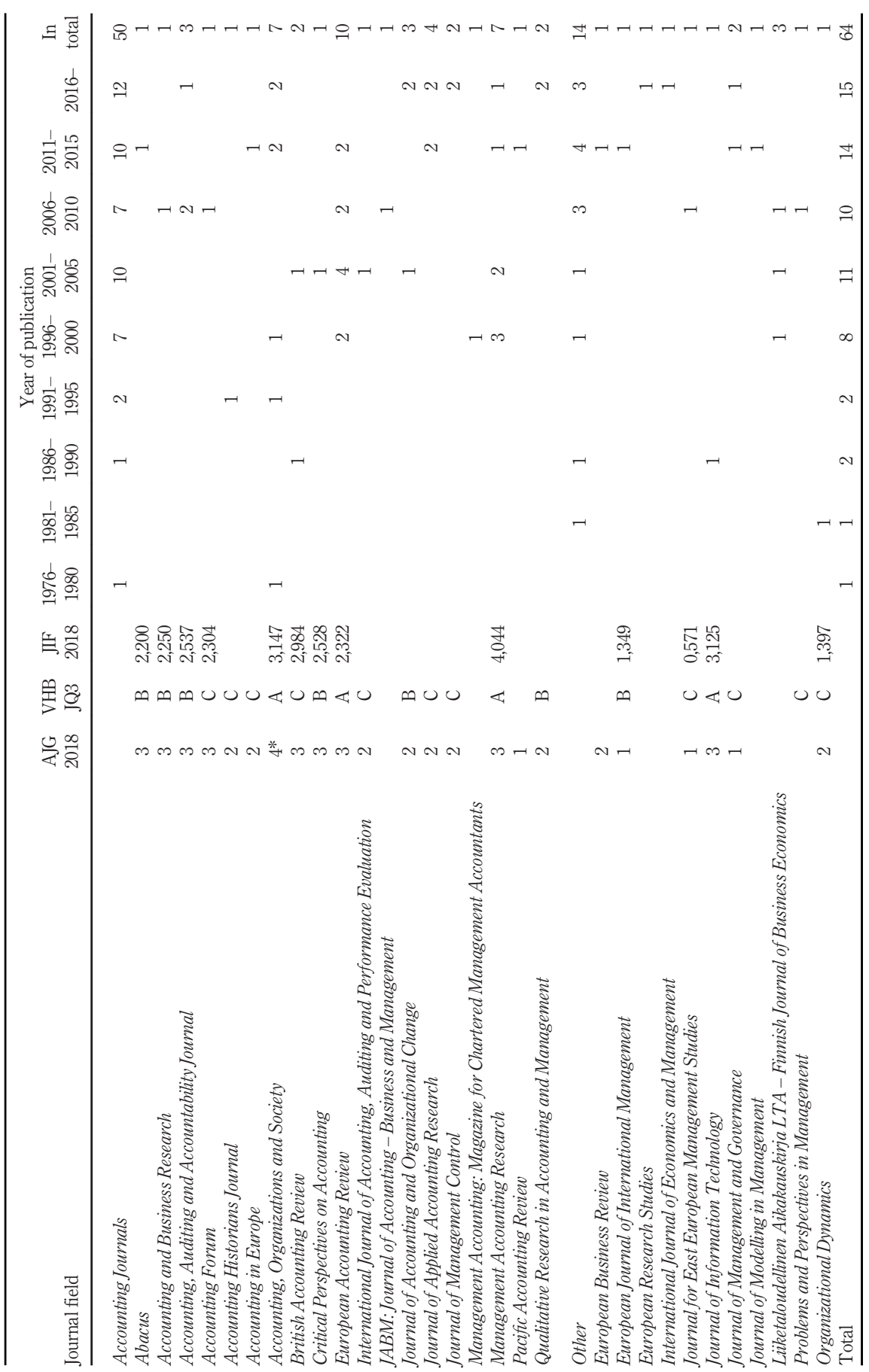

Table 1. Bibliographical information of the reviewed publications 
JAOC
16,3

320

Table 2.

Characteristics of the sample articles

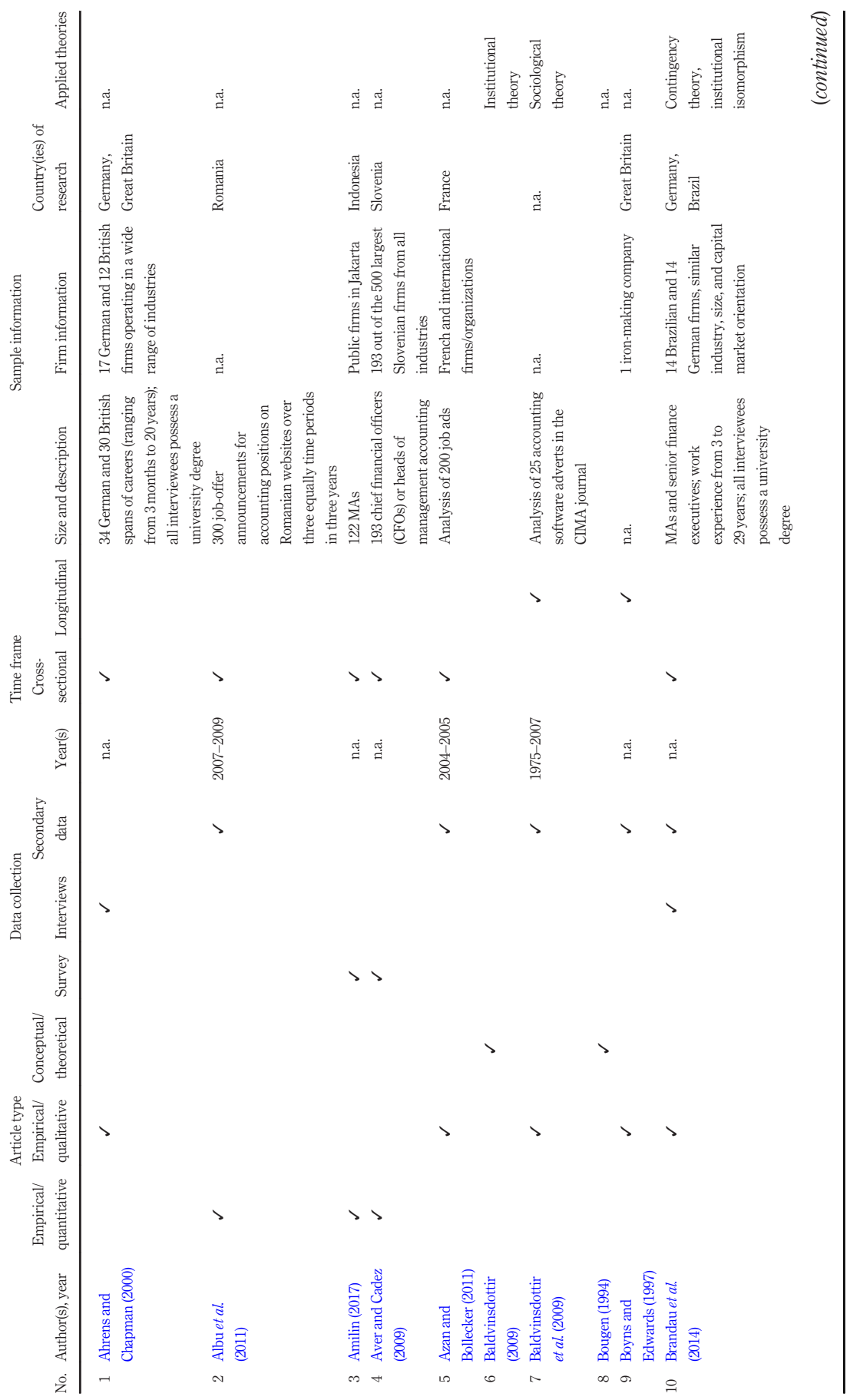




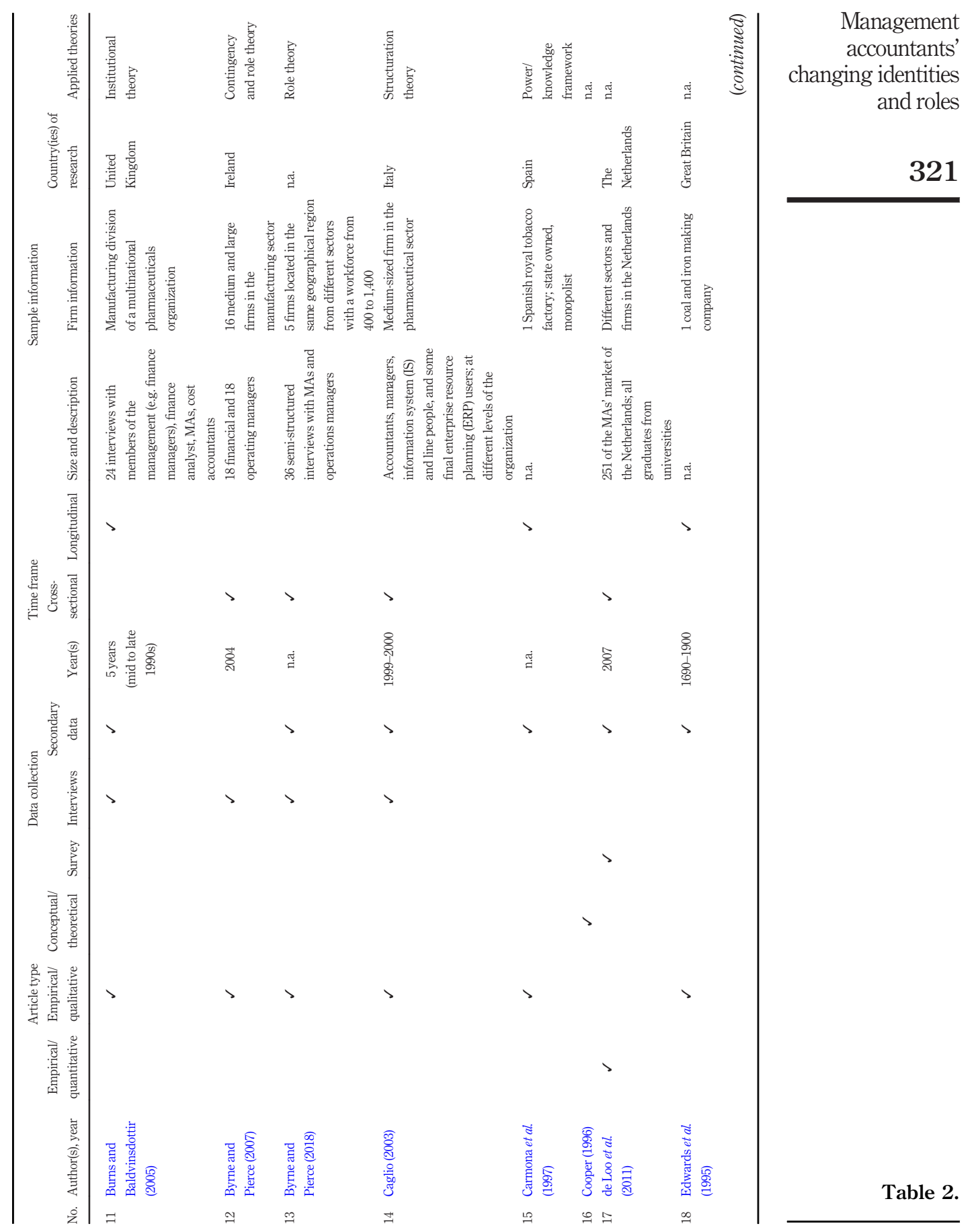



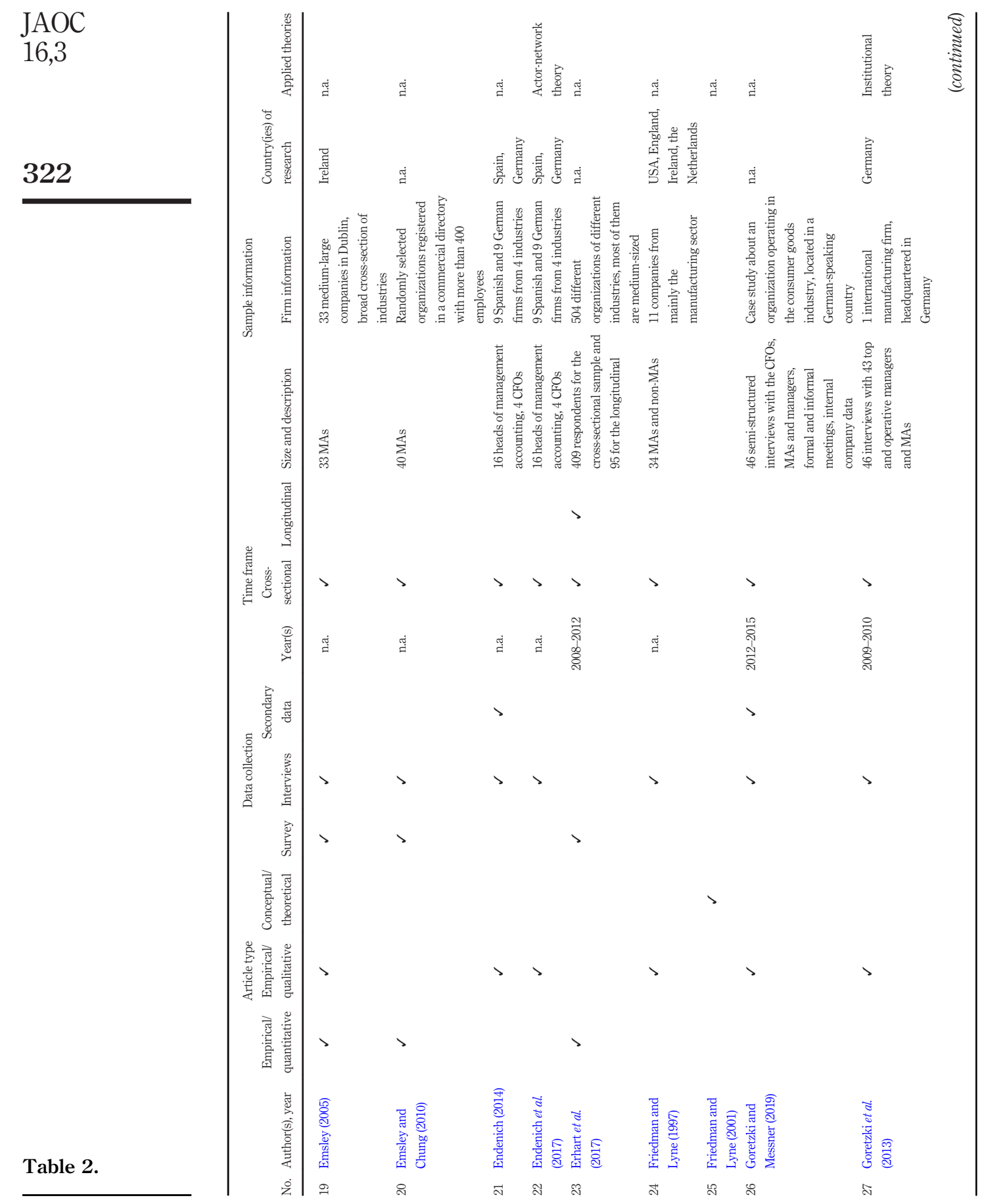

Table 2. 


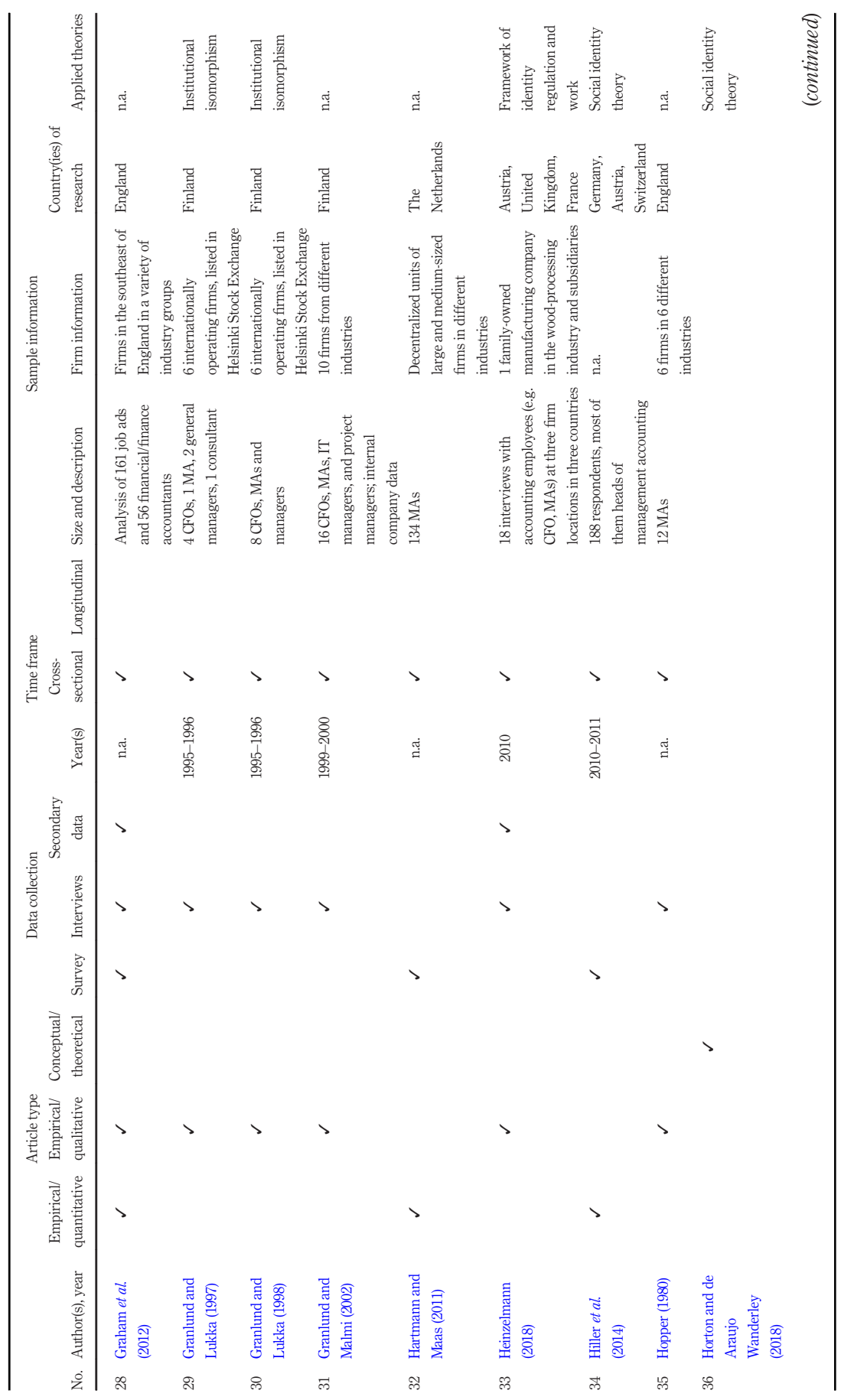

Management accountants' changing identities and roles

323

Table 2. 
JAOC
16,3

324

Table 2.

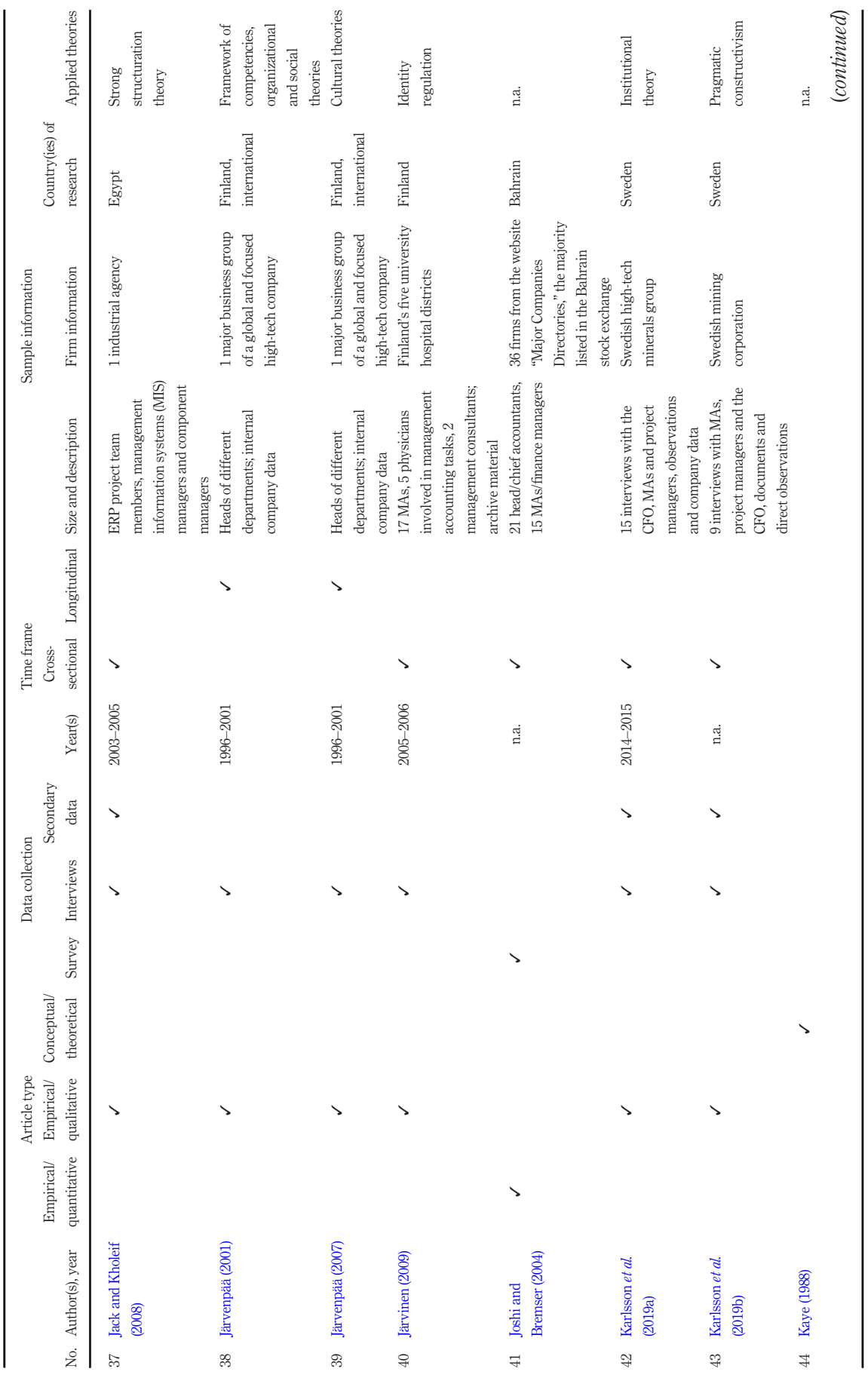




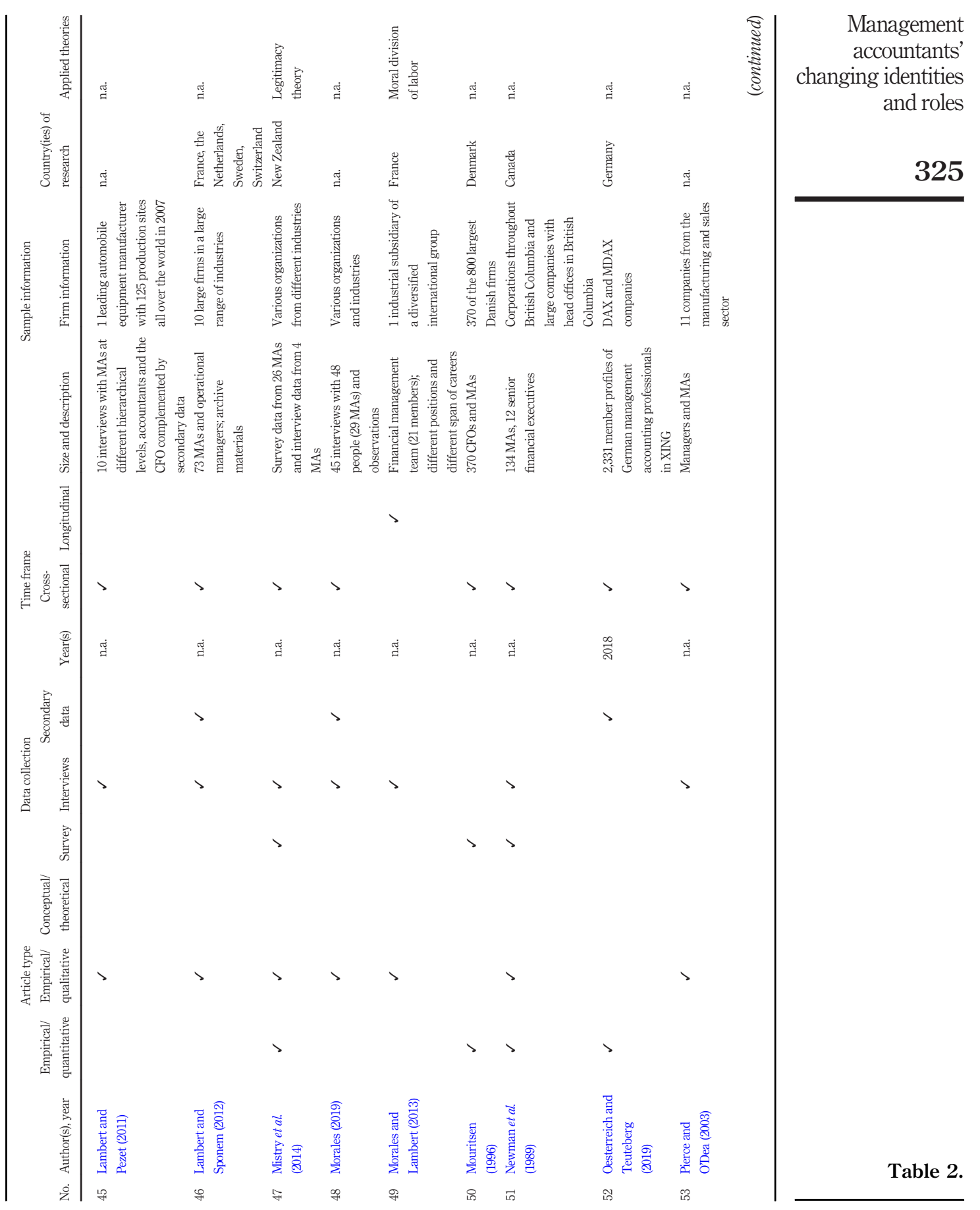


JAOC
16,3

326

Table 2.

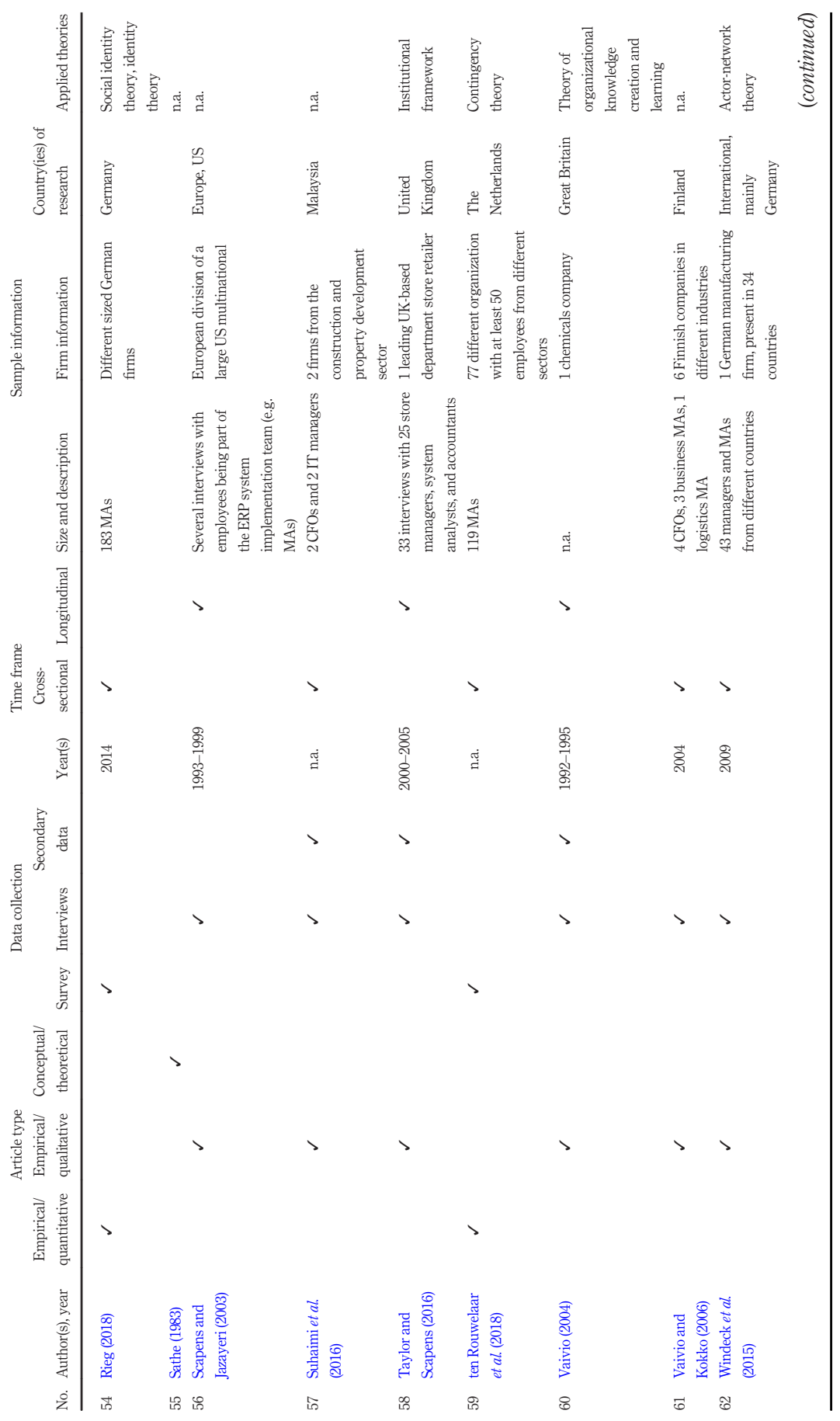



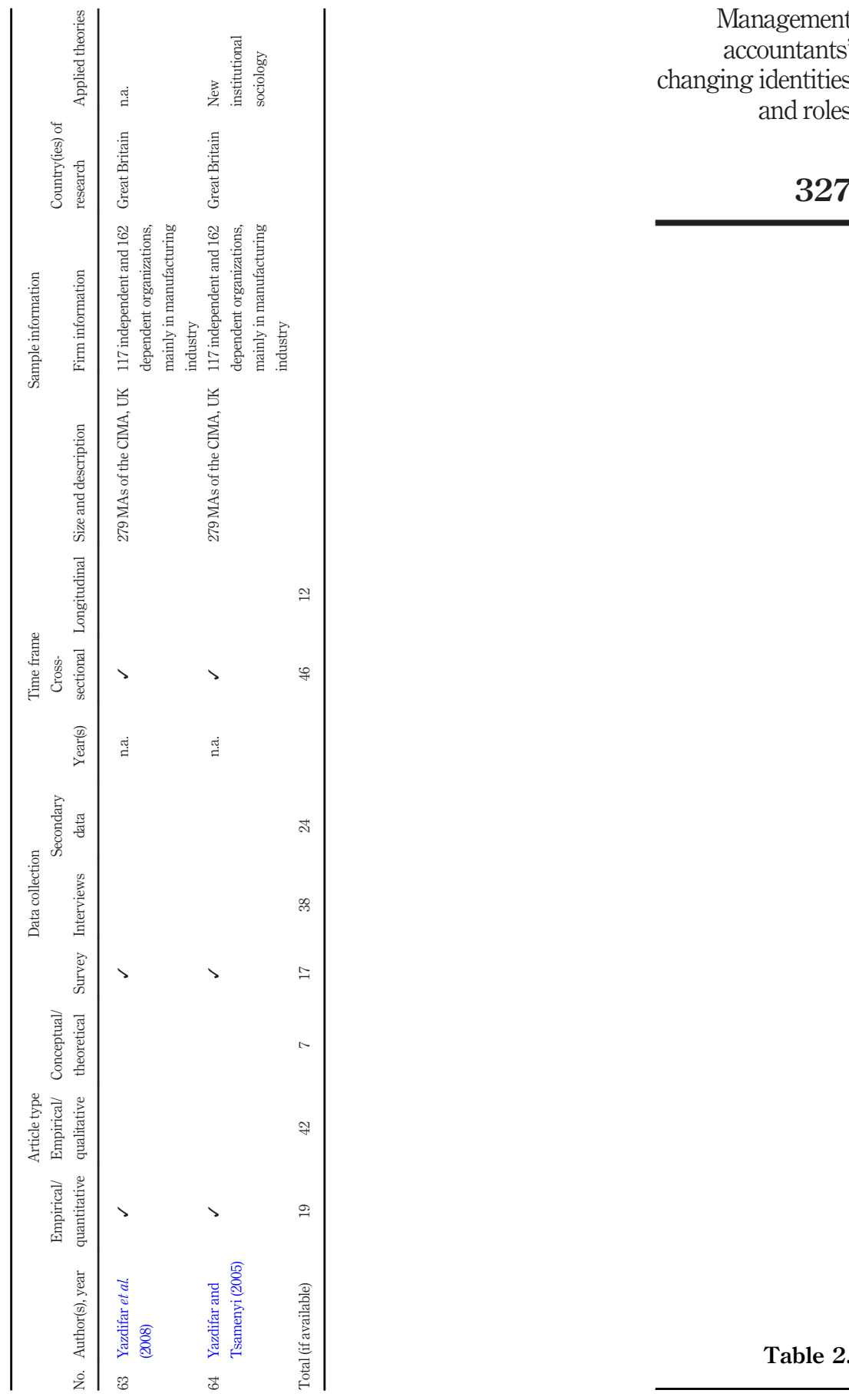
JAOC 16,3

(Kaye, 1988), a theme which is much more intensively discussed in the 2000s (Caglio, 2003; Jack and Kholeif, 2008; Scapens and Jazayeri, 2003; Suhaimi et al., 2016). In the 1990s, there are some historical considerations about MAs (Boyns and Edwards, 1997; Carmona et al., 1997; Edwards et al., 1995). Furthermore, the discussion about stereotypes such as the bean counter (Bougen, 1994; Friedman and Lyne, 1997) and the increasing business orientation of MAs commences (Cooper, 1996; Granlund and Lukka, 1997, 1998). While the debates on bean counter stereotypes are interestingly still a topic in the 2000s (Friedman and Lyne, 2001; Vaivio and Kokko, 2006), business partnering started to dominate the role discussion within academic literature (Byrne and Pierce, 2007; Järvenpää, 2007; Lambert and Sponem, 2012; Rieg, 2018; Windeck et al., 2015). Furthermore, hybrid roles of MAs, who are concomitantly involved in bean counting and business partnering activities, are discussed (Karlsson et al., 2019a; Rieg, 2018; Yazdifar et al., 2008). While in small firms the traditional role pictures prevail (Joshi and Bremser, 2004; de Loo et al., 2011; Mistry et al., 2014), new role terms emerge in large firms, such as the "data scientist," a management accounting specialist for IT issues (Oesterreich and Teuteberg, 2019).

While roles are intensively discussed within academic literature, little is known about identity. Ahrens and Chapman (2000) were the first to explicitly mention the identity of MAs, followed by Järvinen (2009). In the following years, very diverse identity topics such as the link between role changes and identity reconstructions (Goretzki et al., 2013) or the tensions between existing and idealized identities (Morales and Lambert, 2013) were examined. Furthermore, the links between identity and image (Hiller et al., 2014; Taylor and Scapens, 2016) or the impact of IT systems on the identities of MAs (Heinzelmann, 2018) were studied. In the past two years, more complex issues were scrutinized such as multiple identities and identity conflicts (Horton and de Araujo Wanderley, 2018), and the discussion was extended by introducing symbolic categorizations and narratives (Morales, 2019) or clarifying the identity of MAs in a broader interaction context (Goretzki and Messner, 2019).

\section{Findings of the reviewed articles}

Only ten of the analyzed 64 publications explain the identity concept in detail (Ahrens and Chapman, 2000; Goretzki et al., 2013; Goretzki and Messner, 2019; Heinzelmann, 2018; Hiller et al., 2014; Horton and de Araujo Wanderley, 2018; Järvinen, 2009; Morales, 2019; Morales and Lambert, 2013; Taylor and Scapens, 2016). As identities and roles evolve interactively (Barley, 1989; Chreim et al., 2007), it is challenging to differentiate between these two concepts. Many authors talk about role identities, self-perception or self-conceptualization of MAs, and, consequently, they indirectly consider identity. Reflecting on the underlying drivers of identity presented in the theoretical background, we refer to articles if they discuss identity aspects such as characteristics, experiences, motivations, goals, values, beliefs, internal norms and interaction styles of MAs. As outlined in the framework, we concentrate on external, organizational and individual aspects of changing identities.

\subsection{External aspects of the changing identities}

5.1.1 Professional associations and educational institutions. The literature regards professionalization, university research and education as drivers of the change of MAs (Byrne and Pierce, 2007; Granlund and Malmi, 2002; Vaivio and Kokko, 2006). The analyzed literature displays country-specific differences regarding the institutional environment and vocational training (Ahrens and Chapman, 2000; Brandau et al., 2014). In the UK and USA, the institutional context of MAs is based on professional associations whose members pass examinations and complete a minimum period of practical experience which qualify them as professionals (Ahrens and Chapman, 2000). This Anglo-Saxon approach influences English- 
speaking countries, but there are European countries where no professional associations exist, such as Germany or France. Consequently, there is a relatively low recognition of MAs as a profession (Goretzki et al., 2013; Goretzki and Messner, 2019; Lambert and Pezet, 2011), which results in a limited status and requires MAs to undergo a more complex process of socialization and work on the self (Lambert and Pezet, 2011). In countries with a low degree of professionalization, the education is dominated by a very diverging academic education at universities or by private institutions with more practice-oriented training. As there is no certificated training, the vocational training depends more on the managerial expectations or the individual motivation of MAs (Ahrens and Chapman, 2000; Goretzki et al., 2013; Goretzki and Messner, 2019).

Ahrens and Chapman (2000) scrutinize the identity of British and German MAs and state that it is striking how their statements closely resemble the ideas that they received from their institutional context - the CIMA in the UK and German organizations such as the Controller Academy and the International Association of Controllers. Goretzki et al. (2013) describe in their case study that for the reconstruction of identity, the link with an institutional environment is necessary. They mention similar courses at the Controller Academy supporting the adaption of identities, as professionals are encouraged there to act as business partners.

Analyzing the institutional environment of MAs, it is recognizable that members of professional associations, academics, consultants and influential professionals propagate the role of an active business partner. Therefore, the business partner has developed into a legitimate template for MAs (Goretzki et al., 2013). As a result of this external template, MAs tend to perceive their identity in this propagated way, more or less independent from what they really do (Rieg, 2018). Identities are products of purposive actions of professionals who are keen to improve the status of a professional group (Goretzki et al., 2013), and are a clear attempt to distance modern MAs from bean counters (Friedman and Lyne, 2001).

5.1.2 Legislation and compliance. Amendments to the legislation, such as the implementation of the Sarbanes-Oxley act or the tightening of external reporting rules through IFRS, lead to significant changes for MAs. Increased governance regulations influence MAs as they produce more of a control orientation instead of supporting strategic decision-making and business partnering (Byrne and Pierce, 2007; de Loo et al., 2011). Research pays less attention to these control aspects (Emsley and Chung, 2010) but reporting and compliance are gaining importance for MAs (Byrne and Pierce, 2007). Furthermore, the introduction or adaption of risk management is mentioned. Requirements for an efficient risk management increase not only because of legal changes but are also the result of growing risks and external uncertainties. Risk management and compliance have developed into fundamental aspects of the daily work of MAs (de Loo et al., 2011). Therefore, it is questioned how the compliance model can work with the business partner model (Byrne and Pierce, 2007) or how change is hindered by these conflicting priorities (Emsley and Chung, 2010).

Interestingly, as early as the 1980s, Hopper (1980) and Sathe (1983) highlighted possible conflicts caused, on the one hand, by the contribution to business decisions and involvement, and, on the other hand, by control and independence. If MAs become too involved in the business decision-making process, they lose independence, which is required for internal control responsibilities. Byrne and Pierce (2018) still mention MAs' conflict between supporting management processes and maintaining loyalty to financial compliance structures.

5.1.3 Public image. While identity describes how professionals define themselves, image illustrates how professionals suppose that other people define them. Several authors 
JAOC 16,3

(Byrne and Pierce, 2007; Morales and Lambert, 2013; Taylor and Scapens, 2016) discuss the links between identity and image, and that a change in image can cause a change in identity. Regarding these images, we have to be aware about the lacking differentiation between financial accountants and MAs in the English-speaking literature.

Baldvinsdottir et al. (2009) scrutinize the images of MAs represented in advertisements in the CIMA journal. They display that the image has changed from responsible, rational MAs pictured in the 1970s and 1980s to a more adventurous, and powerful image created in the 1990s. For the 1990s, Granlund and Lukka (1997) likewise discovered an increasing business orientation of MAs although the traditional bean counter model yet has a foothold in Finland. Interestingly, Friedman and Lyne (2001) state that the bean counter stereotype is not disappearing and still is a prevailing representation of MAs in the mind of the public. The bean counter stereotype as boring, preoccupied with costs, and attentive to details is often linked with a negative image (Bougen, 1994; Granlund and Lukka, 1998; Friedman and Lyne, 2001), whereas the business partner is presented as an attractive position and ideal among MAs themselves (Järvinen, 2009; Karlsson et al., 2019a). The existence of such external images influences how a group of professionals is regarded within the organization (Järvinen, 2009; Morales and Lambert, 2013).

5.1.4 Concluding remarks concerning external aspects. External aspects such as professionalization, university education and research, legislation and compliance as well as the public image drive identity change. The analyzed literature shows first indications of the influence of professional associations and educational institutions promoting actively the change to business partners. Concerning legislation and compliance, the question arises how the business partner model can work for MAs in case of increased control orientation because of legislation and compliance requirements. It is noteworthy that regardless of propagating the change to business partners, the negative image of the MA is still a topic within the sample publications. Table 3 summarizes the main findings of the sample regarding external aspects of the changing identities.

\subsection{Organizational aspects of the changing identities}

5.2.1 Image within the organization. Public images, as described in the previous section, influence how professionals are esteemed within the organization (Järvinen, 2009; Taylor and Scapens, 2016). Because of criticisms concerning their presumable obsession with costs, their low value-contribution to the organization and their suppression of innovation and creativity, MAs sometimes struggle with a low image in comparison to other professional groups in the organization (Emsley, 2005; Friedman and Lyne, 2001; Pierce and O'Dea, 2003). Thus, professional associations are not the only ones who should care about the image of MAs, this is also a topic within the organizations.

According to Järvinen (2009), the identity of MAs in organizations is associated with their image and perceived role change. Comparably, the case study of Taylor and Scapens (2016) displays a clear relationship between group image, identity and the self-concepts of group members. Positive image and group identity can support individual self-concepts, whereas negative image and group identity can lead to low self-concepts. Hiller et al. (2014) illustrate that MAs' perceived image within organizations influences their identification with the organization and the profession. MAs regard high image as a source of self-esteem and think that they are more accepted by managers. Thus, because of a high image, they may identify more intensely with the organization and its predominant values and norms. Nevertheless, high image may concurrently engender MAs who identify more with their profession, thereby emphasizing high professional standards, transparency and ethical orientation (Hiller et al., 2014). Consequently, if MAs perceive the production of fair and 


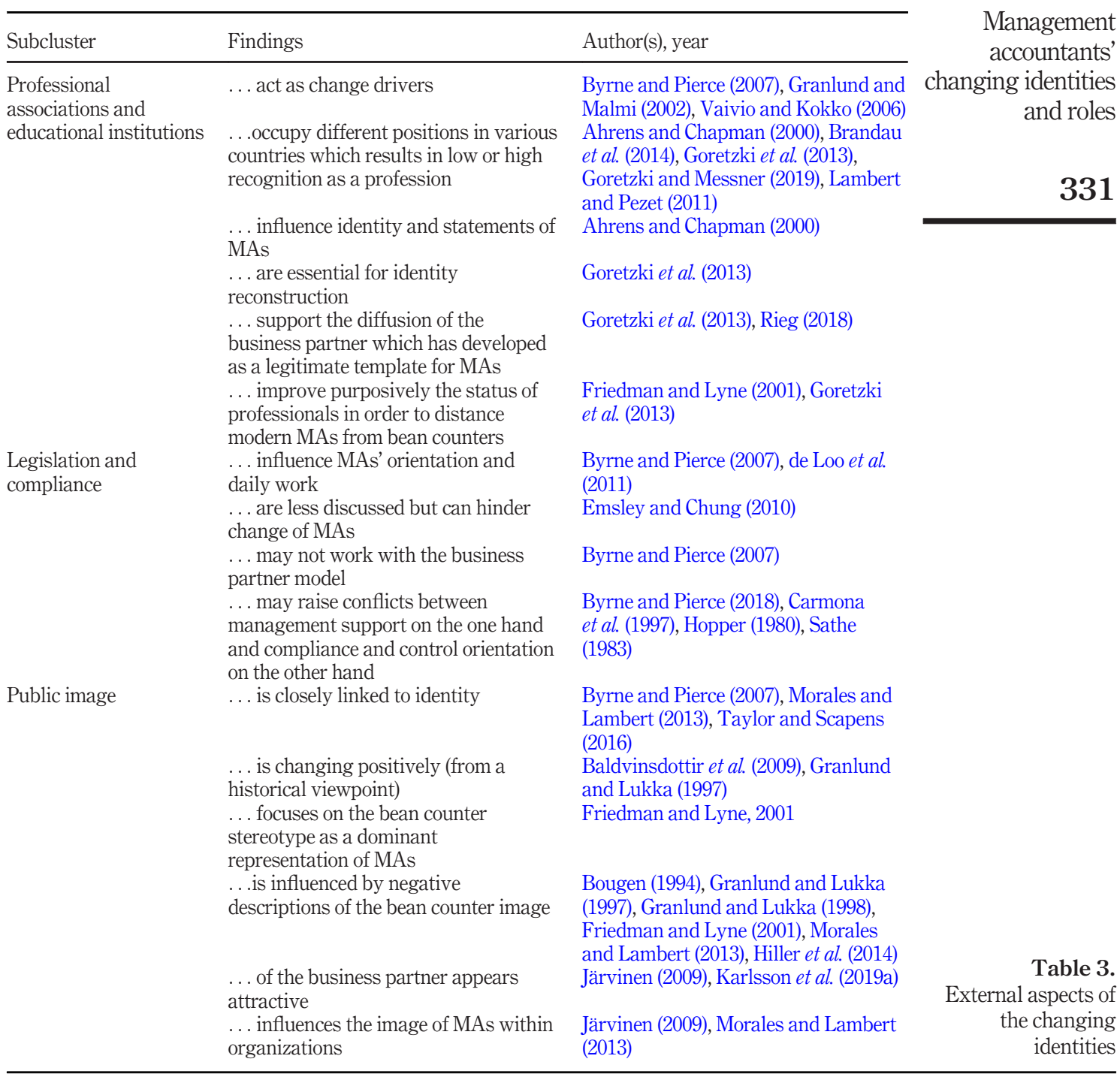

truthful knowledge as constitutive of their identity (Lambert and Pezet, 2011) and if there are incompatibilities between professional and organizational demands, they could become unwilling to compromise for the sake of the organization (Hiller et al., 2014).

5.2.2 Contingency factors. Structuring the literature sample regarding the analyzed organizational contingency factors, it is apparent that the empirical studies within our sample show great differences. Although company size (de Loo et al., 2011; Joshi and Bremser, 2004), industry (Aver and Cadez, 2009), capital market orientation (de Loo et al., 2011; Joshi and Bremser, 2004) and/or ownership structure (Yazdifar et al., 2008) are 
JAOC 16,3

mentioned within the sample literature, just a few authors (Aver and Cadez, 2009; de Loo et al., 2011; Yazdifar et al., 2008) discuss these factors more intensively. Most of the studies examine large firms (Aver and Cadez, 2009; Joshi and Bremser, 2004) and suggest that company size determines the scope of MAs' profession. Several studies (de Loo et al., 2011; Mistry et al., 2014; Oesterreich and Teuteberg, 2019) indicate that bean counting aspects are still essential for MAs operating in smaller sized firms. Notwithstanding the influences of contingency factors, it is remarkable that papers concerning identity emphasize that MAs present in their statements a very coherent and homogeneous discourse about their occupation, values and general orientation (Ahrens and Chapman, 2000; Goretzki and Messner, 2019; Morales, 2019).

MAs can hold a pivotal position in helping organizations to overcome a company crisis; thus, the financial status of an organization is regarded as a specific contingency factor (de Loo et al., 2011; Endenich, 2014). A financial crisis of the company can increase the importance of MAs, when critical situations result in intensified interactions with managers and other departments, as well as in more participation within the decision-making processes. Such critical situations might result in a more influential position and acceptance of MAs (Cooper, 1996; Endenich, 2014). Nonetheless, these consequences have to be considered carefully, as an increased focus on cost reductions in critical financial situations also implies the risk of negative views on MAs (Endenich, 2014).

5.2.3 Information systems and digitalization. MAs are not only affected by IT, but have taken an active part during introduction and development of information systems (Kaye, 1988). Horton and de Araujo Wanderley (2018) predict that changes in management accounting practices will affect MAs' identities. Several authors (Albu et al., 2011; Baldvinsdottir et al., 2009; Suhaimi et al., 2016) regard especially IT systems as important change drivers.

However, there are contradictory findings regarding IT systems. Byrne and Pierce (2007) as well as Suhaimi et al. (2016) argue that developments in IT systems enable MAs to move to a higher analytical level. The case study of Caglio (2003) claims that because of the new IT system, MAs can use their time and expertise more for business management initiatives. This is in contradiction to the studies of Jack and Kholeif (2008) and Heinzelmann (2018), which reveal that the implementation of an IT system does not inevitably direct MAs toward more business orientation. Jack and Kholeif (2008) display that MAs are reduced to traditional information collector and provider. Likewise, Heinzelmann (2018) found that the identities of MAs can be devaluated because of relying too strongly on a new IT system, thus limiting their professional judgment, the choice of tools for analyses and their business insight. Further studies (Granlund and Malmi, 2002; Järvenpää, 2007; Scapens and Jazayeri, 2003) claim that a new IT system can only offer an opportunity for change but is not solely decisive for a role or identity change. Additional factors such as system complexity, time and money (Granlund and Malmi, 2002) or system integration, standardization and routinization (Scapens and Jazayeri, 2003) have to be considered.

The development of IT systems has changed interpersonal relations when communication takes place through integrated tools with less face-to-face interaction (Azan and Bollecker, 2011). Digitalization and the accompanying data increase will intensify these changes. Big data and new data analysis techniques are available with consequences for reporting, analysis and decision-making which will modify how MAs work. Interaction styles of MAs will change because of real-time analyses and decisions (Oesterreich and Teuteberg, 2019).

5.2.4 Patterns of interaction. The interaction with managers and other departments is sharpening the occupational identity (Ahrens and Chapman, 2000; Goretzki and Messner, 
2019). The consequences of more business orientation might be far-reaching as it could mean a conversion from a distant, critical and objective outsider toward an active MA contributing to relations between organizational members (Baldvinsdottir, 2009). Many studies (Byrne and Pierce, 2018; Lambert and Sponem, 2012; Windeck et al., 2015) regard the relationship between managers and MAs as decisive.

Business partnering depends on intense interactions between MAs and managers. However, these relationships are not inherently peaceful, stable and relaxed. Many findings underline difficulties for MAs in interpreting the expectations of managers and coping with tensions arising from situations where managers may not want such involvement (Amilin, 2017; Morales and Lambert, 2013; ten Rouwelaar et al., 2018). Greater involvement of MAs requires a common perspective of MAs and managers, but the business partner model still lacks this common understanding (Byrne and Pierce, 2007; Lambert and Sponem, 2012; Karlsson et al., 2019b).

Accordingly, case field studies show contradictory understandings between MAs and managers what business partnering means. While managers expect primarily support and advice, MAs regard themselves as partners, who do not help managers, but challenge and influence them (Goretzki and Messner, 2019; Morales, 2019). The understanding of MAs' identity is not restricted to the relationships to managers. Moreover, their identity is shaped in a broader context by different types of interactions and their perception of whether people, who are important to MAs, appreciate or disapprove a certain behavior (Goretzki and Messner, 2019).

5.2.5 Decentralization and nested identity. Decentralization of MAs is regarded as a key element for business orientation, because increased proximity changes the values, attitudes and interactions of MAs (Järvenpää, 2007; Pierce and O'Dea, 2003; Vaivio, 2004). The closer cooperation and proximity to managers and other departments influence MAs' identities, because MAs work within organizations with a distinguishable identity and, at the same time, within workgroups with a certain understanding of their identities. Thus, members of professional groups may identify stronger with their workgroup than with similar professional groups. Therefore, workplace identities are regarded as nested identities (Horton and de Araujo Wanderley, 2018).

The case study of Taylor and Scapens (2016) shows different identities of accountants "inside" and "outside" an accounting department. The term "management accountant" does not necessarily signify a common mind-set. Recognizing that workgroups can be distinct entities with their own separate identity, the ways of acting of MAs in different parts of an organization or in different locations might be closer to their local managerial colleagues than to other MAs in the organization (Lambert and Sponem, 2012; Taylor and Scapens, 2016).

5.2.6 Concluding remarks concerning organizational aspects. Identity is linked with image and perceived role changes; furthermore, the image of MAs within the organization influences their identification with the organization and profession. A closer analysis of the contingency factors in the literature sample displays that we rely mainly on findings of large organizations concerning the changing roles and identities of MAs. Moreover, the consequences of the financial situation of an organization for MAs are to be assessed carefully. Ambiguous results are accessible concerning IT systems, which can provide more time for business partnering, but MAs can concurrently feel restricted by IT systems. In addition, digitalization and the accompanying data increase influence MAs and their interaction styles. Concerning patterns of interaction, there is a focus on the relationship to managers but a broader interaction context is relevant for the changing identity of MAs. Decentralization is proposed as the most promising way to change values, attitudes and
Management accountants' changing identities and roles 
JAOC 16,3

interactions of MAs. Their location in different departments leads to a nested identity implying that MAs rather identify with their workgroup than with their professional groups in the organization. Table 4 offers a synthesis of findings from the identified articles on organizational aspects of the changing identities.

\subsection{Individual aspects of the changing identities}

5.3.1 Multiple identities. Multiple identities imply that MAs refer to a variety of different identities at their workplaces. Diverse foci, interests and time dimensions represent these multiple identities. Different identities may stand for different levels of analysis; for instance, an individual's perception as an MA compared with the organization's collective consideration of MAs. Organizations are the general context, but subgroups such as financial managers specify the platform for career ambitions. Identities of MAs are recurrently interconnected with managers' or external institutions' ideas of MAs. Furthermore, individuals may embrace different notions of identities which they desire for the future (Horton and de Araujo Wanderley, 2018).

The literature illustrates a fragmented and contradictory picture of the MA. Despite the popular template of the business partner, there are hybrid MAs who are concurrently involved in bean counting and business partnering (Burns and Baldvinsdottir, 2005; Vaivio and Kokko, 2006), indicating multiple identities. Main drivers for hybrid MAs are among others accounting regulations, internal performance monitoring policies, financial control systems as well as MAs' individual preferences, personality and initiative (Byrne and Pierce, 2007; Karlsson et al., 2019a).

5.3.2 Identity conflicts. Nowadays, MAs are esteemed because of their participation in decision-making processes, although they have concurrently internal control responsibilities. Thus, possible conflicts - already discussed in the 1980s - are still emphasized, in particular the independence-involvement problem (Byrne and Pierce, 2007; Lambert and Sponem, 2012; Pierce and O'Dea, 2003). However, recent findings of Byrne and Pierce (2018) extend the work on conflicts beyond the independence-involvement dilemma and display a broad range of conflicts caused by conflicting, ambiguous, over- and underloaded expectations of managers perceived by MAs. Likewise, Goretzki and Messner (2019) display that regardless of the rather positive discussion about business partnering, such changes are not free of conflicts. Despite the creation of job profiles or organizational units to provide possibilities for MAs to become business partners, this aspirational identity remains fragile and leaves MAs with a continuing insecure feeling of "still not being there."

On the one hand, identity conflicts are important because they show the need for change. Horton and de Araujo Wanderley (2018) provide a process model of identity conflicts by beginning with exploring multiple identities characterizing MAs, explaining the potential conflicts between these different identities and displaying behavioral responses of MAs to conflicts to diminish the perceived discrepancies. On the other hand, conflicts indicate that the idea of business partnering is still ambiguous and uncertain (Byrne and Pierce, 2007) because some MAs might shape themselves with the business partner model, a more exciting identity to fulfil their personal interests. Other MAs might have valid reasons to evade positioning themselves as business partners (Burns and Baldvinsdottir, 2005; Granlund and Lukka, 1998).

5.3.3 Competencies and characteristics. Business orientation leads to an increasing emphasis on new competencies without a reduction of the old ones. Social competencies are gaining significance, as MAs depend on functioning networks to communicate their information and to convey their ideas. Cooperation, intuitions and understanding the 


\begin{tabular}{|c|c|c|c|}
\hline Subcluster & Findings & Author(s), year & \\
\hline $\begin{array}{l}\text { Image within the } \\
\text { organization }\end{array}$ & $\begin{array}{l}\text {... and stereotypes influence identity, } \\
\text { role change and self-concept } \\
\ldots \text { is low when MAs are compared to } \\
\text { other professionals } \\
\ldots \text { influences MAs' identification with } \\
\text { the organization and the profession } \\
\ldots \text {. is constitutive of MAs' identity }\end{array}$ & $\begin{array}{l}\text { Friedman and Lyne (2001), Järvinen } \\
\text { (2009), Pierce and O'Dea (2003), Sathe } \\
\text { (1983), Taylor and Scapens (2016) } \\
\text { Emsley (2005), Friedman and Lyne } \\
\text { (2001), Pierce and O'Dea (2003) } \\
\text { Hiller et al. (2014) }\end{array}$ & $\begin{array}{r}\text { accountants } \\
\text { changing identities } \\
\text { and roles } \\
\\
\mathbf{3 3 5}\end{array}$ \\
\hline \multirow[t]{4}{*}{ Contingency factors } & $\begin{array}{l}\text { the organization and the profession } \\
\ldots \text { is constitutive of MAs' identity } \\
\text { Company size determines the scope of } \\
\text { MAs' profession }\end{array}$ & $\begin{array}{l}\text { Lambert and Pezet (2011) } \\
\text { de Loo et al. (2011), Joshi and Bremser } \\
\text { (2004), Mistry et al. (2014), Oesterreich } \\
\text { and Teuteberg (2019) }\end{array}$ & \\
\hline & $\begin{array}{l}\text { Other factors such as capital market } \\
\text { orientation, ownership, industries, } \\
\text { organizational level of MA function, } \\
\text { contextual uncertainty and the use of } \\
\text { the budgetary system }\end{array}$ & $\begin{array}{l}\text { Aver and Cadez (2009), de Loo et al. } \\
\text { (2011), Hartmann and Maas (2011), } \\
\text { Joshi and Bremser (2004), Yazdifar } \\
\text { et al. (2008) }\end{array}$ & \\
\hline & $\begin{array}{l}\ldots \text { do not preclude very homogeneous } \\
\text { discourse of MAs about their } \\
\text { occupation, values and general } \\
\text { orientation }\end{array}$ & $\begin{array}{l}\text { Ahrens and Chapman (2000), Goretzki } \\
\text { and Messner (2019), Morales (2019) }\end{array}$ & \\
\hline & $\begin{array}{l}\text { Financial distress of organizations can } \\
\text { increase importance of MAs }\end{array}$ & $\begin{array}{l}\text { Cooper (1996), de Loo et al. (2011), } \\
\text { Endenich (2014) }\end{array}$ & \\
\hline \multirow{3}{*}{$\begin{array}{l}\text { Information } \\
\text { systems and } \\
\text { digitalization }\end{array}$} & $\begin{array}{l}\text {... are actively developed and } \\
\text { implemented by MAs }\end{array}$ & Kaye (1988) & \\
\hline & $\begin{array}{l}\text {... effect changes in MAs' roles, } \\
\text { identities and interactions styles }\end{array}$ & $\begin{array}{l}\text { Albu et al. (2011), Azan and Bollecker } \\
\text { (2011), Baldvinsdottir } \text { et al. (2009), } \\
\text { Byrne and Pierce (2007), Järvenpää } \\
\text { (2007), Jack and Kholeif (2008), Caglio } \\
\text { (2003), Granlund and Malmi (2002), } \\
\text { Horton and de Araujo Wanderley } \\
\text { (2018), Kaye (1988), Oesterreich and } \\
\text { Teuteberg (2019), Scapens and } \\
\text { Jazayeri (2003), Suhaimi et al. (2016), } \\
\text { Yazdifar and Tsamenyi (2005), } \\
\text { Yazdifar } \text { et al. (2008) }\end{array}$ & \\
\hline & $\begin{array}{l}\ldots \text {. can lead to devaluation of MAs if } \\
\text { relied on too intensively } \\
\ldots \text { are solely an opportunity for } \\
\text { changes }\end{array}$ & $\begin{array}{l}\text { Heinzelmann (2018), Jack and Kholeif } \\
\text { (2008) } \\
\text { Granlund and Malmi (2002), Järvenpää } \\
\text { (2007), Scapens and Jazayeri (2003) }\end{array}$ & \\
\hline \multirow[t]{4}{*}{$\begin{array}{l}\text { Patterns of } \\
\text { interaction }\end{array}$} & ... influence identities and roles & $\begin{array}{l}\text { Ahrens and Chapman (2000), } \\
\text { Baldvinsdottir (2009), Goretzki and } \\
\text { Messner (2019) }\end{array}$ & \\
\hline & $\begin{array}{l}\text {... between MAs and managers are } \\
\text { especially decisive }\end{array}$ & $\begin{array}{l}\text { Byrne and Pierce (2018), Mouritsen } \\
\text { (1996), Lambert and Sponem (2012), } \\
\text { Windeck et al. (2015) }\end{array}$ & \\
\hline & ... result in tensions and difficulties & $\begin{array}{l}\text { Amilin (2017), Byrne and Pierce (2007), } \\
\text { Byrne and Pierce (2018), Edwards } \\
\text { et al. (1995), Morales and Lambert } \\
\text { (2013), ten Rouwelaar } \text { et al. (2018) }\end{array}$ & $\begin{array}{r}\text { Table } 4 . \\
\text { Organizational }\end{array}$ \\
\hline & & (continued) & $\begin{array}{l}\text { aspects of the } \\
\text { changing identities }\end{array}$ \\
\hline
\end{tabular}




\section{JAOC 16,3}

Decentralization and nested identity

\begin{tabular}{ll}
\hline Subcluster & Findings \\
\hline & $\begin{array}{l}\text {.. would benefit from a mutual } \\
\text { but is impaired by different attributed } \\
\text { meanings }\end{array}$ \\
$\begin{array}{l}\text { Decentralization } \\
\text { and nested identity }\end{array}$ & $\begin{array}{l}\text { thus identity or role } \\
\text { thence }\end{array}$
\end{tabular}

... make MAs identify stronger with their workgroups than with occupational group
Author(s), year

Byrne and Pierce (2007), Goretzki and Messner (2019), Karlsson et al. (2019b), Lambert and Sponem (2012), Morales (2019)

Goretzki et al. (2013), Granlund and Lukka (1998), Järvenpää (2007), Lambert and Sponem (2012), Pierce and O'Dea (2003), Vaivio (2004), Järvenpää (2007), ten Rouwelaar et al. (2018)

Horton and de Araujo Wanderley (2018), Lambert and Sponem (2012), Taylor and Scapens (2016)

Table 4.

business are essential for the future development of MAs (Endenich et al., 2017; Järvenpää, 2001; Pierce and O'Dea, 2003).

Regarding IT-competencies, Azan and Bollecker (2011) demonstrate the need for MAs to be able to use IT-systems competently. Technological progress broadens their competencies, as it demands, for instance, programming and algorithmic skills. Oesterreich and Teuteberg (2019) show that digitalization requests further new competencies concerning business analytics and IT. They refer to professional associations such as IMA, which try to incorporate these new competencies by updating their competence frameworks. However, they clearly state that the current competence profiles of MAs do not comply with the latest requirements concerning business analytics competencies. Regarding all the requested competencies, MAs might perceive some of these as incompatible. Ahrens and Chapman (2000) have already presented in their comparison of MAs that the persons interviewed experienced incompatible characteristics, such as being assertive and co-operative, theoretical and commercially minded, objective and intuitive.

5.3.4 Desired and ideal identity. Besides the current identity, also the desired future identity frames the interpretations of MAs (Taylor and Scapens, 2016; Morales, 2019). Business orientation is presented as increasing MAs' value and standing in organizations, and thus it can be regarded as a desired or ideal identity (Goretzki and Messner, 2019; Graham et al., 2012). MAs aspire an identity in line with their values and standards, but frequently recognize some misalignment between what the profession currently stands for and how it should be in the future. Differences between current and desired identities indicate a threat of self-esteem, when the ideals of a desired identity seem too incompatible with the real identity. These incompatibilities are connected with negative conclusions, but concurrently represent a stimulus for change, as professionals try to increase self-esteem by pursuing more consistent and esteemed identities (Heinzelmann, 2018; Horton and de Araujo Wanderley, 2018).

The case study of Taylor and Scapens (2016) shows, for instance, that an unsatisfying identity can motivate individuals to promote changes toward a desired future identity. Morales (2019) emphasizes the importance of symbolic categorizations and narratives through which MAs build a bridge between what they do, who they are and an ideal identity. By using more prestigious titles for the work of MAs, it is possible to disguise those activities which are perceived by MAs as low-prestige and thus demonstrate their added value. Morales and Lambert (2013) illustrate discrepancies between existing and ideal 
identities in a French organization where they scrutinize MAs who could not become "fully" business-oriented, which generates tensions in their self-identity. MAs acting more as bookkeepers may judge this as a personal failure undermining their self. The identity of professionals depends on their situation vis-à-vis other occupations, and professionals consequently strive for the most prestigious occupation. An identity may be destabilized or continue to be vulnerable when the self-view is obviously incompatible with the desired identity. This is interpreted by the MAs as demeaning and diminishing the construction of a valuable identity as business partners.

5.3.5 Concluding remarks concerning individual aspects. Because of different foci, interests and time dimensions, multiple identities can evolve during change processes and the debate about the hybrid MA refers directly to multiple identities. Most of the literature implicitly suggests that the change to business orientation is a positive development, but the commitment of MAs to meet such requirements can cause identity conflicts when they are not able to fulfil the perceived expectations. Our literature sample displays that business orientation requires changes in competencies, and thus MAs sometimes perceive all the requested competencies as incompatible. MAs do not only reflect about their current identity but also about desired and ideal identities, thereby recognizing the divergences and striving for more concordance between these identities. Table 5 presents findings on individual aspects of the changing identities within the sample articles.

\section{Summary, conclusion, implications and limitations}

\subsection{Summary and conclusion}

Our literature sample illustrates a fragmented and contradictory picture regarding the changing identities and roles of MAs. Furthermore, the review displays how identity is closely interconnected with the enactment of roles; thus, it is challenging to separate these two concepts in the analysis as the papers use these terms interchangeably. Although we analyze the changes of MAs, some topics have remained the same for several years or decades. The sample starts with conflicts between independence and involvement of MAs (Hopper, 1980) and conflicts are still being discussed 40 years later (Amilin, 2017; Byrne and Pierce, 2018; Horton and de Araujo Wanderley, 2018). Hybrid MAs are mentioned first by Caglio (2003) and are still themed by Karlsson et al. (2019b). A possible reason for this hybrid picture can be that management accounting itself can be regarded as a hybrid as it was formed at the margins and out of a range of practices from other disciplines (Miller et al., 2008).

This paper contributes to the existing literature by providing the first systematic overview from an identity perspective based on a sample of 64 publications. Although identity is closely connected with the implementation of new roles (Chreim et al., 2007; Goretzki et al., 2013), the review displays that only a few publications explain the identity concept in detail. At an early stage of research, identity of MAs has emerged as a separate research field (Morales, 2019) with very diverse topics and concepts of identity. Given the wide range of articles and variety of themes, it is challenging to draw overall conclusions. However, reflecting on the research question and the conceptual framework, various fresh insights can be gained.

Change and its prospects are likely to initiate concerns about identity (Jenkins, 2014). Therefore, the paper aims, at first, to provide a comprehensive understanding of the ongoing changes concerning MAs by focusing on an identity perspective. It clearly displays that the idea of a simple movement from one optimal identity to another is ambiguous and misleading (Burns and Scapens, 2000; Karlsson et al., 2019a). Second, the review contributes to existing research by displaying first indications of the influence of professional
Management accountants'

changing identities and roles 


\section{JAOC 16,3}

\begin{tabular}{ll} 
Subcluster & Findings \\
\hline Multiple identities & $\begin{array}{l}\text {.. are represented by diverse foci, } \\
\text { interests, and time dimensions } \\
\ldots \text { are exemplified by hybrid MAs }\end{array}$
\end{tabular}

\section{8}

Identity conflicts

Competencies and characteristics

Desired and ideal identity

\section{Table 5.}

Individual aspects of the changing identities $\ldots$ as manifestation of the involvement-independence dilemma

... caused by conflicting, ambiguous, over- and underloaded expectations of managers

... despite or as a result of the idea of business partnering

... getting more important (especially social competencies)

... of MAs are influenced by technological progress

... of MAs reflect skill gaps (e.g., business analytics)

... that are requested are perceived as incompatible by MAs

... frames the interpretation of MAs

... manifests itself in business partnering

... may conflict with current and dayto-day identity

... may promote change

$\ldots$ is threatened by perceived lowprestige activities
Author(s), year

Horton and de Araujo Wanderley (2018)

Burns and Baldvinsdottir (2005), Byrne and Pierce (2007), Caglio (2003), Horton and de Araujo Wanderley (2018), Karlsson et al. (2019a), Rieg (2018), Vaivio and Kokko (2006), Yazdifar et al. (2008)

Byrne and Pierce (2007), Goretzki and Messner (2019), Hopper (1980), Horton and de Araujo Wanderley (2018), Lambert and Sponem (2012), Pierce and O'Dea (2003), Sathe (1983)

Byrne and Pierce (2018)

Burns and Baldvinsdottir (2005), Byrne and Pierce (2007), Goretzki and Messner (2019), Granlund and Lukka (1998), Horton and de Araujo Wanderley (2018)

Endenich et al. (2017), Järvenpää (2001), Newman et al. (1989), Pierce and O'Dea (2003), Sathe (1983), ten Rouwelaar et al. (2018)

Azan and Bollecker (2011)

Oesterreich and Teuteberg (2019)

Ahrens and Chapman (2000)

Taylor and Scapens (2016), Morales (2019)

Byrne and Pierce (2007), Graham et al. (2012), Goretzki and Messner (2019), Järvinen (2009), Lambert and Sponem (2012), Morales and Lambert (2013) Heinzelmann (2018), Horton and de Araujo Wanderley (2018)

Taylor and Scapens (2016)

Morales (2019), Morales and Lambert (2013)

associations and educational institutions on change processes of MAs by providing prevalent templates. Moreover, findings indicate that the promoted business partner model challenges MAs if legislation and compliance require a higher level of control orientation. It is remarkable that regardless of propagating the change to business partners, the negative public image of the MA is still a topic. Concerning organizational aspects, the close link between perceived image, identity and role changes is emphasized. The analysis of organizational contingency factors reveals that we rely mainly on findings of large firms, which accounts for a very small selection of the variety of organizations. The review 
identifies ambiguous results regarding the impacts of the financial situation of an organization, contradictory findings regarding the change driver "IT systems" and uncertainties how digitalization will affect MAs' identities and roles. The patterns of interaction illustrate that managers can be simultaneously a source of stability and fragility for MAs' changing identities. Additionally, to managers as their focal audience, there is the relevance of a broader interaction context for MAs' identities. Decentralization is regarded as a key element for business orientation but may lead to a nested identity, implying that MAs identify more with their workgroups than with similar professional groups within the organization. We comprehend that different foci and interests in organizations cause multiple identities. Most of the literature implicitly indicates that the change to business orientation is positive and that MAs wish to be business-oriented, but their commitment to fulfil such normative demands can cause tensions. Thus, identity conflicts show the need for change, but indicate concurrently that the idea of business partnering is still not straightforward. Concerning the changing competencies of MAs, our sample shows that business orientation leads to increasing new competencies without reducing the old ones. Therefore, the description of the business partner becomes more a narrative of an omnipotent thought leader who is able to combine incompatible requirements. Not only the current identity, but also the desired identity frames the interpretations of MAs and they may support those changes, which are consistent with their desired identities.

What is especially novel because of the identity perspective is the focus on MAs and their internal views, perceptions and internalized meanings connected with their role instead of debating exclusively external behavior expectations. These perceptions are particularly recognizable within the discussion of the individual aspects, for instance, their struggle with multiple identities, inner conflicts, incompatible competencies, multiple and desired identities.

\subsection{Implications for research, practice and education}

As there are just a few studies about identity in detail, numerous implications for future research exist. Clear identities and a transition from one identity to another may be too simplistic, and thus future research should avoid simple classifications and concentrate more on the complexity. It would be interesting to explore how some professionals succeed in creating a picture of homogeneity, which in practice might be a fragile compromise but one that allows emphasizing a legitimate picture of a profession (Morales and Lambert, 2013).

As we have only a few preliminary suggestions about the influence of professional and educational institutions (Goretzki et al., 2013), scholars might scrutinize this institutional influence more intensely. Regarding legislation and compliance, more studies are needed to explain how business partnering can work with compliance and control requirements. As most of the analyses concentrate on larger companies, more studies could focus on small and middle-sized companies to comply with the variety of organizations. Furthermore, more research about additional contingency factors would broaden our knowledge.

Because of contradictory findings regarding IT systems, we agree completely with Caglio (2003) and propose that more interpretive case studies about IT systems are required to identify their complex impacts. Our sample included just one paper discussing digitalization as a new challenge (Oesterreich and Teuteberg, 2019) and this calls for further research regarding the impacts of digitalization on the identities of MAs, e.g. concerning the impacts on interaction styles of MAs or their orientation toward the challenge of transforming data to knowledge (Bhimani and Willcocks, 2014). The subjects of decentralization and nested identities need more research to illustrate under which 
JAOC 16,3

conditions MAs might identify more with their workgroups than with similar professional groups within the organization.

In addition to nested identity, the identity perspective delivers new subjects for management accounting research such as multiple or desired identities. Little is still known about the individual aspects of MAs' identities; thus, we follow Horton and de Araujo Wanderley (2018) and call for more efforts to understand multiple identities and identity conflicts. The hybridization of MAs would need further research. Burns and Baldvinsdottir (2005) describe the hybridization of MAs in their case study as relatively unproblematic, but call for case studies that allow investigating possible tensions and conflicts more in-depth. Finally, more research would be interesting regarding the desired identities of MAs. Not much research has been accomplished on the challenge that MAs as business partners expand their profession, which may be regarded as threatening by management and other departments (Burns et al., 2014; Lambert and Sponem, 2012; Rieg, 2018).

The results of this review are of high practical relevance for daily interactions in companies. As business partners, MAs develop intensive relationships with managers and members of other departments which might be easier if MAs are aware of their identities. Business partnering goes along with a more prestigious perception and a higher level of involvement by MAs, which may not be welcomed by all organizational members and thus cause tensions. There are implications especially for the working relationships in multinational companies where MAs work together and are influenced by different professional associations and educational institutions. Nested identity may be a concern within companies, because of the possibility that MAs identify more with their close work colleagues than with their profession in the organization. Moreover, findings may also change recruitment practices. In addition to external role expectations, internal self-views and internalized beliefs might be discussed with applicants during the staffing process in management accounting.

Furthermore, there are implications for education as management accounting students can be encouraged to occupy themselves with their identity, self-view, characteristics and values instead of exclusively discussing external expectations of their potential future profession. Regarding the new generation $Z$ with its focus on personal fulfillment, the identity perspective enables students to reflect their personal and possible appropriate professional identities. In addition, management accounting students should become aware how developments in legislation and compliance, IT and digitalization or organizational and personal characteristics shape MAs' work, orientation and interaction styles and thus their identities. The identity concept offers a broad range of novel topics for courses at educational institutions such as nested identity, multiple or desired identities.

\subsection{Limitations}

Finally, we have to mention the limitations of our systematic literature review. Our sample is restricted to English-language journal publications. However, other languages, non-peerreviewed and/or practitioner journals as well as other publication modes (e.g. books, conference papers, working papers) could also provide useful findings about MAs' changing identities. Moreover, the nature of the search process, the choice of the specific keywords and the exclusion process, which is based on subjective valuations, involve the risk of having not identified all relevant publications. Although we conducted all stages of the search process with great care and accuracy, the search process could be criticized. Furthermore, we are aware that the identity concept is generated out of diverse disciplines such as psychology, anthropology, sociology and other social sciences and that our explanations show just a small selection of this comprehensive research area. 


\section{Notes}

1. Google Scholar is a search engine mainly for scholarly publications, and available online at https://scholar.google.com

2. The Academic Journal Guide (AJG) 2018 published by the Chartered Association of Business Schools (CABS) can be found at https://charteredabs.org/academic-journal-guide-2018/

3. The JOURQUAL3 (JQ3) ranking from the German Academic Association for Business Research (VHB) is available at https://vhbonline.org/vhb4you/jourqual/vhb-jourqual-3/gesamtliste/

4. We refer to Journal Impact Factors (JIF) found in InCites Journal Citation Reports from Thomson Reuters, located at https://jcr.incites.thomsonreuters.com/

\section{References}

*Ahrens, T. and Chapman, C.S. (2000), "Occupational identity of management accountants in britain and Germany", European Accounting Review, Vol. 9 No. 4, pp. 477-498.

*Albu, C.N., Albu, N., Faff, R. and Hodgson, A. (2011), "Accounting competencies and the changing role of accountants in emerging economies: the case of Romania”, Accounting in Europe, Vol. 8 No. 2, pp. 155-184.

Alvesson, M. and Willmott, H. (2002), "Identity regulation as organizational control: producing the appropriate individual”, Journal of Management Studies, Vol. 39 No. 5, pp. 619-644.

*Amilin, A. (2017), "The impact of role conflict and role ambiguity on accountants' performance: the moderating effect of emotional quotient”, European Research Studies Journal, Vol. 20 No. 2A, pp. 237-249.

Ashforth, B.E. (2001), Role Transitions in Organizational Life: An Identity-Based Perspective, Lawrence Erlbaum Associates, Mahwah, NJ.

Ashforth, B.E. and Mael, F. (1989), "Social identity theory and the organization", Academy of Management Review, Vol. 14 No. 1, pp. 20-39.

Ashforth, B.E., Harrison, S.H. and Corley, K.G. (2008), "Identification in organizations: an examination of four fundamental questions", Journal of Management, Vol. 34 No. 3, pp. 325-374.

*Aver, B. and Cadez, S. (2009), "Management accountants' participation in strategic management process: a cross-industry comparison", Journal of East European Management Studies, Vol. 14 No. 3, pp. 310-322.

*Azan, W. and Bollecker, M. (2011), "Management control competencies and ERP: an empirical analysis in France", Journal of Modelling in Management, Vol. 6 No. 2, pp. 178-199.

*Baldvinsdottir, G.H. (2009), "Management accounting and the institutionalization of trust", Problems and Perspectives in Management, Vol. 7 No. 2, pp. 53-60.

*Baldvinsdottir, G.H., Burns, J., Nørreklit, H. and Scapens, R.W. (2009), "The image of accountants: from bean counters to extreme accountants", Accounting, Auditing and Accountability Journal, Vol. 22 No. 6, pp. 858-882.

Barley, S.R. (1989), "Careers, identities, and institutions: the legacy of the Chicago school of sociology", in Arthur, M.B., Hall, D.T. and Lawrence, B.S. (Eds), Handbook of Career Theory, Cambridge University Press, Cambridge, pp. 41-65.

Bhimani, A. and Willcocks, L. (2014), "Digitisation, 'big data' and the transformation of accounting information", Accounting and Business Research, Vol. 44 No. 4, pp. 469-490.

Biddle, B.J. (1986), "Recent developments in role theory", Annual Review of Sociology, Vol. 12 No. 1, pp. 67-92.

Biddle, B.J. (2013), Role Theory: Expectations, Identities, and Behaviors, Academic Press, New York, NY.
Management accountants' changing identities and roles 
*Bougen, P.D. (1994), "Joking apart: the serious side to the accountant stereotype", accounting", Organizations and Society, Vol. 19 No. 3, pp. 319-335.

*Boyns, T. and Edwards, J.R. (1997), "Cost and management accounting in early Victorian Britain: a chandleresque analysis?”, Management Accounting Research, Vol. 8 No. 1, pp. 19-46.

*Brandau, M., Hoffjan, A. and Wömpener, A. (2014), "The globalisation of a profession: comparative management accounting in emerging and developed countries", European J. Of International Management, Vol. 8 No. 1, pp. 73-105.

Brewer, M.B. (1999), "Multiple identities and identity transition: implications for Hong Kong", International Journal of Intercultural Relations, Vol. 23 No. 2, pp. 187-197.

Brewer, M.B. and Gardner, W. (1996), "Who is this 'We'? levels of collective identity and self representations”, Journal of Personality and Social Psychology, Vol. 71 No. 1, pp. 83-93.

Burke, P.J. and Reitzes, D.C. (1981), "The link between identity and role performance", Social Psychology Quarterly, Vol. 44 No. 2, pp. 83-92.

Burke, P.J. and Stets, J.E. (2009), Identity Theory, Oxford University Press, New York, NY.

Burke, P.J. and Tully, J.C. (1977), "The measurement of role identity", Social Forces, Vol. 55 No. 4, pp. 881-897.

*Burns, J. and Baldvinsdottir, G.H. (2005), “An institutional perspective of accountants' new roles - the interplay of contradictions and praxis", European Accounting Review, Vol. 14 No. 4, pp. 725-757.

Burns, J. and Scapens, R.W. (2000), "Conceptualizing management accounting change: an institutional framework", Management Accounting Research, Vol. 11 No. 1, pp. 3-25.

Burns, J., Warren, L. and Oliveira, J. (2014), "Business partnering: is it all that good?", Controlling and Management Review, Vol. 58 No. 2, pp. 36-41.

*Byrne, S. and Pierce, B. (2007), "Towards a more comprehensive understanding of the roles of management accountants", European Accounting Review, Vol. 16 No. 3, pp. 469-498.

*Byrne, S. and Pierce, B. (2018), "Exploring management accountants' role conflicts and ambiguities and how they cope with them", Qualitative Research in Accounting and Management, Vol. 15 No. 4, pp. 410-436.

*Caglio, A. (2003), "Enterprise resource planning systems and accountants: towards hybridization?", European Accounting Review, Vol. 12 No. 1, pp. 123-153.

*Carmona, S., Ezzamel, M. and Gutiérrez, F. (1997), "Control and cost accounting practices in the Spanish royal tobacco factory”, accounting”, Organizations and Society, Vol. 22 No. 5, pp. 411-446.

Chenhall, R.H. (2003), "Management control systems design within its organizational context findings from contingency-based research and directions for the future", accounting", Organizations and Society, Vol. 28 Nos 2/3, pp. 127-168.

Chreim, S., Williams, B.E. and Hinings, C.R. (2007), "Interlevel influences on the reconstruction of professional role identity", Academy of Management Journal, Vol. 50 No. 6, pp. 1515-1539.

*Cooper, R. (1996), "Look out, management accountants", Management Accounting: Magazine for Chartered Management Accountants, Vol. 74 No. 5, pp. 20-26.

Cooper, D.J. and Robson, K. (2006), "Accounting, professions and regulation: locating the sites of professionalization”, accounting”, Organizations and Society, Vol. 31 Nos 4/5, pp. 415-444.

*de Loo, I., Verstegen, B. and Swagerman, D. (2011), "Understanding the roles of management accountants”, European Business Review, Vol. 23 No. 3, pp. 287-313.

Dutton, J.E. and Dukerich, J.M. (1991), "Keeping an eye on the mirror: image and identity in organizational adaptation”, Academy of Management Journal, Vol. 34 No. 3, pp. 517-554.

*Edwards, J.R., Boyns, T. and Anderson, M. (1995), "British cost accounting development: continuity and change”, Accounting Historians Journal, Vol. 22 No. 2, pp. 1-41. 
*Emsley, D. (2005), "Restructuring the management accounting function: a note on the effect of role involvement on innovativeness", Management Accounting Research, Vol. 16 No. 2, pp. 157-177.

*Emsley, D. and Chung, L.H. (2010), "How management accountants' cognitive style and role involvement combine to affect the effort devoted to initiating change", Abacus, Vol. 46 No. 3 , pp. 232-257.

*Endenich, C. (2014), "Economic crisis as a driver of management accounting change: comparative evidence from Germany and Spain", Journal of Applied Accounting Research, Vol. 15 No. 1, pp. 123-149.

*Endenich, C., Trapp, R. and Brandau, M. (2017), "Management accounting networks in corporate processes - a cross-national study", Journal of Accounting and Organizational Change, Vol. 13 No. 1, pp. 25-43.

*Erhart, R., Mahlendorf, M.D., Reimer, M. and Schäffer, U. (2017), "Theorizing and testing bidirectional effects: the relationship between strategy formation and involvement of controllers", accounting”, Organizations and Society, Vol. 61, pp. 36-52.

*Friedman, A.L. and Lyne, S.R. (1997), "Activity-based techniques and the death of the beancounter", European Accounting Review, Vol. 6 No. 1, pp. 19-44.

*Friedman, A.L. and Lyne, S.R. (2001), "The beancounter stereotype: towards a general model of stereotype generation", Critical Perspectives on Accounting, Vol. 12 No. 4, pp. 423-451.

Giddens, A. (1991), Modernity and Self-Identity: self and Society in the Lade Modern Age, Stanford University Press, Stanford, CA.

Gioia, D.A. and Thomas, J.B. (1996), "Identity, image, and issue interpretation: sensemaking during strategic change in academia", Administrative Science Quarterly, Vol. 41 No. 3, pp. 370-403.

Glynn, M.A. (2008), "Beyond constraint: how institutions enable identities”, in Greenwood, R., Oliver, C., Suddaby, R. and Sahlin, K. (Eds), Handbook of Organizational Institutionalism, Sage Publications, London, pp. 413-430.

*Goretzki, L. and Messner, M. (2019), "Backstage and frontstage interactions in management accountants' identity work", Accounting Organizations and Society, Vol. 74, pp. 1-20.

*Goretzki, L., Strauss, E. and Weber, J. (2013), "An institutional perspective on the changes in management accountants' professional role”, Management Accounting Research, Vol. 24 No. 1, pp. 41-63.

*Graham, A., Davey-Evans, S. and Toon, I. (2012), "The developing role of the financial controller: evidence from the UK", Journal of Applied Accounting Research, Vol. 13 No. 1, pp. 71-88.

*Granlund, M. and Lukka, K. (1997), "From bean-counters to change agents: the Finnish management accounting culture in transition", Liiketaloudellinen Aikakauskirja LTA - Finnish Journal of Business Economics, Vol. 1 No. 3, pp. 213-255.

*Granlund, M. and Lukka, K. (1998), "Towards increasing business orientation: Finnish management accountants in a changing cultural context”, Management Accounting Research, Vol. 9 No. 2 , pp. 185-211.

*Granlund, M. and Malmi, T. (2002), "Moderate impact of ERPS on management accounting: a lag or permanent outcome?", Management Accounting Research, Vol. 13 No. 3, pp. 299-321.

*Hartmann, F.G.H. and Maas, V.S. (2011), "The effects of uncertainty on the roles of controllers and budgets: an exploratory study", Accounting and Business Research, Vol. 41 No. 5, pp. 439-458.

Haslam, S.A. and Ellemers, N. (2011), "Identity processes in organizations", in Schwartz, S.J., Luyckx, K. and Vignoles, V.L. (Eds), Handbook of Identity Theory and Research, Springer, New York, NY, pp. $715-744$.

*Heinzelmann, R. (2018), "Occupational identities of management accountants: the role of the IT system”, Journal of Applied Accounting Research, Vol. 19 No. 4, pp. 465-482.

Management accountants' changing identities and roles

\section{$-$}

(1) 
JAOC 16,3

*Hiller, K., Mahlendorf, M.D. and Weber, J. (2014), "Management accountants' occupational prestige within the company: a social identity theory perspective", European Accounting Review, Vol. 23 No. 4, pp. 671-691.

Hogg, M.A. and Abrams, D. (1988), Social Identifications: A Social Psychology of Intergroup Relations and Group Processes, Routledge, London.

*Hopper, T.M. (1980), "Role conflicts of management accountants and their position within organisation structures", Accounting Organizations and Society, Vol. 5 No. 4, pp. 401-411.

*Horton, K.E. and de Araujo Wanderley, C. (2018), "Identity conflict and the paradox of embedded agency in the management accounting profession: adding a new piece to the theoretical jigsaw", Management Accounting Research, Vol. 38, pp. 39-50.

Institute of Management Accountants (IMA) (2008), Definition of Management Accounting, Montvale, NJ.

*Jack, L. and Kholeif, A. (2008), "Enterprise resource planning and a contest to limit the role of management accountants: a strong structuration perspective", Accounting Forum, Vol. 32 No. 1, pp. 30-45.

*Järvenpää, M. (2001), "Connecting management accountants changing roles, competencies and personalities into the wider managerial discussion - a longitudinal case evidence from the modern business environment", Liiketaloudellinen Aikakauskirja LTA - Finnish Journal of Business Economics, Vol. 5 No. 4, pp. 431-458.

*Järvenpää, M. (2007), "Making business partners: a case study on how management accounting culture was changed”, European Accounting Review, Vol. 16 No. 1, pp. 99-142.

*Järvinen, J. (2009), "Shifting NPM agendas and management accountants' occupational identities", Accounting, Auditing and Accountability Journal, Vol. 22 No. 8, pp. 1187-1210.

Jenkins, R. (2014), Social Identity, Routledge.

*Joshi, P.L. and Bremser, W.G. (2004), "Changing dimensions of accountants' role and skill requirements in organisations: findings from the corporate sector in Bahrain", International Journal of Accounting, Auditing and Performance Evaluation, Vol. 1 No. 3, pp. 363-384.

*Karlsson, B., Hersinger, A. and Kurkkio, M. (2019a), "Hybrid accountants in the age of the business partner: exploring institutional drivers in a mining company", Journal of Management Control, Vol. 30 No. 2, pp. 185-211.

*Karlsson, B., Kurkkio, M. and Hersinger, A. (2019b), "The role of the controller in strategic Capital investment projects: bridging the gap of multiple topoi", Journal of Management and Governance, Vol. 23 No. 3, pp. 813-838.

*Kaye, G.R. (1988), "The role of management accountants in information strategy", Journal of Information Technology, Vol. 3 No. 4, pp. 251-264.

Kielhofner, G. (2002), A Model of Human Occupation: theory and Application, Lippincott Williams and Wilkins, Philadelphia, PA.

Kreiner, G.E., Hollensbe, E.C. and Sheep, M.L. (2006), "On the edge of identity: boundary dynamics at the interface of individual and organizational identities", Human Relations, Vol. 59 No. 10, pp. 1315-1341.

Kubíček, A. and Machek, O. (2018), "Gender-related factors in family business succession: a systematic literature review”, Review of Managerial Science, Vol. 13 No. 5, pp. 1-40.

*Lambert, C. and Pezet, E. (2011), "The making of the management accountant - becoming the producer of truthful knowledge", accounting", Organizations and Society, Vol. 36 No. 1, pp. 10-30.

*Lambert, C. and Sponem, S. (2012), "Roles, authority and involvement of the management accounting function: a multiple case-study", European Accounting Review, Vol. 21 No. 3, pp. 565-589. 
Lawrence, T.B. and Suddaby, R. (2006), "Institutions and institutional work", in Clegg, S., Hardy, C., Lawrence, T.B. and Nord, W.R. (Eds), The Sage Handbook of Organization Studies, Sage Publications, Thousand Oaks, pp. 215-254.

Linton, R. (1936), The Study of Man: An Introduction, D. Appleton-Century Co., New York, NY, London.

Massaro, M., Dumay, J. and Guthrie, J. (2016), "On the shoulders of giants: undertaking a structured literature review in accounting”, Accounting, Auditing and Accountability Journal, Vol. 29 No. 5, pp. 767-801.

Miller, P., Kurunmäki, L. and O'Leary, T. (2008), "Accounting, hybrids and the management of risk", accounting”, Organizations and Society, Vol. 33 Nos 7/8, pp. 942-967.

*Mistry, V., Sharma, U. and Low, M. (2014), "Management accountants' perception of their role in accounting for sustainable development: an exploratory study", Pacific Accounting Review, Vol. 26 Nos 1/2, pp. 112-133.

*Morales, J. (2019), "Symbolic categories and the shaping of identity", Qualitative Research in Accounting and Management, Vol. 16 No. 2, pp. 252-278.

*Morales, J. and Lambert, C. (2013), "Dirty work and the construction of identity. An ethnographic study of management accounting practices", accounting", Organizations and Society, Vol. 38 No. 3, pp. 228-244.

*Mouritsen, J. (1996), "Five aspects of accounting departments", work", Management Accounting Research, Vol. 7 No. 3, pp. 283-303.

Ndemewah, S.R., Menges, K. and Hiebl, M.R. (2019), "Management accounting research on farms: what is known and what needs knowing?", Journal of Accounting and Organizational Change, Vol. 15 No. 1, pp. 58-86.

*Newman, M., Smart, C. and Vertinsky, I. (1989), "Occupational role dimensions: the profession of management accounting”, The British Accounting Review, Vol. 21 No. 2, pp. 127-140.

Nguyen, D.H., Weigel, C. and Hiebl, M.R.W. (2018), "Beyond budgeting: review and research agenda", Journal of Accounting and Organizational Change, Vol. 14 No. 3, pp. 314-337.

*Oesterreich, T.D. and Teuteberg, F. (2019), "The role of business analytics in the controllers and management accountants' competence profiles: an exploratory study on individual-level data", Journal of Accounting and Organizational Change, Vol. 15 No. 2, pp. 330-356.

Oyserman, D. and James, L. (2011), "Possible identities", in Schwartz, S.J., Luyckx, K. and Vignoles, V.L. (Eds), Handbook of Identity Theory and Research, Springer, New York, NY, pp. 117-145.

Oyserman, D., Elmore, K. and Smith, G. (2012), "Self, self-concept, and identity", in Leary, M.R. and Tangney, J.P. (Eds), Handbook of Self and Identity, Guilford Press, New York, NY, pp. 69-104.

*Pierce, B. and O'Dea, T. (2003), "Management accounting information and the needs of managers: perceptions of managers and accountants compared", The British Accounting Review, Vol. 35 No. 3, pp. 257-290.

Postmes, T. and Jetten, J. (2006), "Reconciling individuality and the group", in Postmes, T. and Jetten, J. (Eds), Individuality and the Group: advances in Social Identity, Sage, London, pp. 258-269.

Pratt, M.G., Rockmann, K.W. and Kaufmann, J.B. (2006), "Constructing professional identity: the role of work and identity learning cycles in the customization of identity among medical residents", Academy of Management Journal, Vol. 49 No. 2, pp. 235-262.

*Rieg, R. (2018), "Tasks, interaction and role perception of management accountants: evidence from Germany", Journal of Management Control, Vol. 29 No. 2, pp. 183-220.

*Sathe, V. (1983), "The controller's role in management", Organizational Dynamics, Vol. 11 No. 3, pp. 31-48. 
JAOC 16,3

*Scapens, R.W. and Jazayeri, M. (2003), "ERP systems and management accounting change: opportunities or impacts? A research note", European Accounting Review, Vol. 12 No. 1, pp. 201-233.

Schwartz, S.J., Luyckx, K. and Vignoles, V.L. (Eds) (2011), Handbook of Identity Theory and Research, Springer, New York, NY.

Scott, W.R. (2008), Institutions and Organizations: ideas and Interests, Sage, Los Angeles.

Senftlechner, D. and Hiebl, M.R.W. (2015), "Management accounting and management control in family businesses: past accomplishments and future opportunities", Journal of Accounting and Organizational Change, Vol. 11 No. 4, pp. 573-606.

Skorikov, V.B. and Vondracek, F.W. (2011), "Occupational identity”, in Schwartz, S.J., Luyckx, K. and Vignoles, V.L. (Eds), Handbook of Identity Theory and Research, Springer, New York, NY, pp. 693-714.

Sorensen, J.E. (2009), "Management accountants in the United States: practitioner and academic views of recent developments", Handbooks of Management Accounting Research, Vol. 3, pp. 1271-1296.

Stets, J.E. and Burke, P.J. (2000), "Identity theory and social identity theory", Social Psychology Quarterly, Vol. 63 No. 3, pp. 224-237.

Stryker, S. (1980), Symbolic Interactionism: A Social Structural Version, Benjamin-Cummings, San Francisco, CA.

Stryker, S. and Burke, P.J. (2000), “The past, present, and future of identity theory”, Social Psychology Quarterly, Vol. 63 No. 4, pp. 284-297.

*Suhaimi, N.S.A., Nawawi, A. and Salin, A.S.A.P. (2016), "Impact of enterprise resource planning on management control system and accountants' role", International Journal of Economics and Management, Vol. 10 No. 1, pp. 93-108.

Tajfel, H. (1978), “An integrative theory of intergroup conflict", in Tajfel, H. (Ed.), Differentiation between Social Groups: Studies in the Social Psychology of Intergroup Relations, Academic Press, London, pp. 61-76.

Tajfel, H. (1981), Human Groups and Social Identity - Studies in Social Psychology, Cambridge University Press, Cambridge.

Tajfel, H. and Turner, J. (1979), "An integrative theory of intergroup conflict", in Austin, W.G. and Worchel, S. (Eds), The Social Psychology of Intergroup Relations, Brooks/Cole Publishing Company, Pacific Grove, CA, pp. 33-47.

*Taylor, L.C. and Scapens, R.W. (2016), "The role of identity and image in shaping management accounting change", Accounting, Auditing and Accountability Journal, Vol. 29 No. 6, pp. 1075-1099.

*ten Rouwelaar, H., Bots, J. and de Loo, I. (2018), "The influence of management accountants on managerial decisions", Journal of Applied Accounting Research, Vol. 19 No. 4, pp. 442-464.

Thoits, P.A. (1983), "Multiple identities and psychological well-being: a reformulation and test of the social isolation hypothesis", American Sociological Review, Vol. 48 No. 2, pp. 174-187.

Thoits, P.A. (1986), "Multiple identities: examining gender and marital status differences in distress", American Sociological Review, Vol. 51 No. 2, pp. 259-272.

Tranfield, D., Denyer, D. and Smart, P. (2003), "Towards a methodology for developing evidenceinformed management knowledge by means of systematic review", British Journal of Management, Vol. 14 No. 3, pp. 207-222.

*Vaivio, J. (2004), "Mobilizing local knowledge with 'provocative' non-financial measures", European Accounting Review, Vol. 13 No. 1, pp. 39-71.

*Vaivio, J. and Kokko, T. (2006), "Counting big: re-examining the concept of the bean counter controller", Liiketaloudellinen Aikakauskirja LTA - Finnish Journal of Business Economics, Vol. 55 No. 1, pp. 49-74. 
Verstegen, B.H.J., de Loo, I., Mol, P., Slagter, K. and Geerkens, H. (2007), "Classifying controllers by activities: an exploratory study", Journal of Applied Management Accounting Research, Vol. 5 No. 2, pp. 9-32.

Vignoles, V.L., Schwartz, S.J. and Luyckx, K. (2011), "Introduction: toward an integrative view of identity", in Schwartz, S.J., Luyckx, K. and Vignoles, V.L. (Eds), Handbook of Identity Theory and Research, Springer, New York, NY, pp. 1-27.

*Windeck, D., Weber, J. and Strauss, E. (2015), "Enrolling managers to accept the business partner: the role of boundary objects", Journal of Management and Governance, Vol. 19 No. 3, pp. 617-653.

Wolf, S., Weißenberger, B.E., Wehner, C.M. and Kabst, R. (2015), "Controllers as business partners in managerial decision-making: attitude, subjective norm, and internal improvements", Journal of Accounting and Organizational Change, Vol. 11 No. 1, pp. 24-46.

*Yazdifar, H., Askarany, D. and Askary, S. (2008), "Management accountants' role in dependent and independent companies: does ownership matter?", JABM Journal of Accounting - Business and Management, Vol. 15 No. 2, pp. 1-21.

*Yazdifar, H. and Tsamenyi, M. (2005), "Management accounting change and the changing roles of management accountants: a comparative analysis between dependent and independent organizations", Journal of Accounting and Organizational Change, Vol. 1 No. 2, pp. 180-198.

\section{Corresponding author}

Tanja Wolf can be contacted at: tanja.wolf@jku.at
Management accountants'

changing identities and roles

For instructions on how to order reprints of this article, please visit our website: www.emeraldgrouppublishing.com/licensing/reprints.htm Or contact us for further details: permissions@emeraldinsight.com 